\title{
UM FUNERAL "DIGNO": \\ CELEBRAÇÕES DA MORTE \\ NA IRMANDADE DE NOSSA SENHORA DO ROSÁRIO \\ E SÃO BENEDITO, FLORIANÓPOLIS (1888-1925)
}

Karla Leandro Rascke*

\section{A Irmandade de Nossa Senhora do Rosário e São Benedito ${ }^{1}$ de Florianópolis}

As irmandades são organizações religiosas criadas na Idade Média, entre os séculos XII e XV, na Europa, com o objetivo inicial de congregar fiéis em torno da devoção a um santo padroeiro. Essas associações seguiam regras internas estabelecidas em um compromisso que definia objetivos, obrigações dos irmãos, deveres, formas de entrada, taxas de pagamento, etc. Os compromissos dividem-se em capítulos que tratam dos objetivos da irmandade, da condição jurídico-civil daqueles que poderiam ser aceitos como irmãos, e também de seus direitos e deveres, sua forma de organização, além de questões religiosas e sociais. Apesar de surgirem por meio do catolicismo, eram organizadas por homens e mulheres leigas. Essas irmandades passavam pelas instâncias da Igreja e, dependendo do reino e da época, deviam passar, também, pelas instâncias do Estado principalmente nas regiões nas quais vigorou o padroado, a exemplo da ibérica - , para aprovação, mas eram mantidas, organizadas e administradas pelos irmãos leigos, que compunham uma mesa administrativa. Além

* Pesquisadora associada ao Núcleo de Estudos Afro-Brasileiros da Universidade do Estado de Santa Catarina, Diretora Administrativa do Instituto de Estudos Culturais Luisa Mahin.

1 A irmandade passou a ser assim denominada a partir da reformulação do Compromisso, em 1905. Antes tinha a denominação "dos homens pretos", muito comum à época e por serem os cargos da Mesa assumidos por esta "qualidade" de homens. Durante a elaboração desse trabalho, perceberemos melhor essas mudanças, não apenas no nome, mas no sentido da associação, cujo foco principal passou a ser a beneficência. 
da finalidade religiosa, as irmandades tinham função social, auxiliando na resolução de problemas econômicos, prestando assistência em caso de doenças ou desamparo e pobreza. ${ }^{2}$

No século XVIII, as irmandades remetiam seus compromissos a Lisboa, para aprovação da Coroa, motivando, inclusive, o cuidado com esses documentos, em vista da demora na autorização e da remessa necessária a Portugal para aprovação. Até a República, “em função do Padroado Régio, estes estatutos compromissais deveriam ser aprovados tanto pela Igreja Católica quanto pelo Estado", representando o poder temporal e o espiritual, respectivamente.

Consultar: Antonia Aparecida Quintão, Lá vem o meu parente: as irmandades de pretos e pardos no Rio de Janeiro e em Pernambuco (século XVIII), São Paulo: Annablume/Fapesp, 2002; Catherine Vincent, Les confréries médiévales dans le royaume de France - XIIIe-XVe siècle, Paris: Albin Michel, 1994; André Vauchez, A espiritualidade da Idade Média Ocidental séc. VIII-XIII, Lisboa: Estampa, 1995; Alicia Bazarte Martínez, Las cofradías de españoles en la ciudad de México (1526-1860), México, D.F.: Universidad Autónoma Metropolitana, Unidad Azcapotzalco, División de Ciencias Sociales y Humanidades, 1989; Thomas Calvo, "Le blanc manteau de l'urbanisation sur l'Amérique hispanique (1550-1600)", Perspectivas Históricas, n.5-6, (2000), pp.12-62; Penteado, "Fontes para a história das confrarias: algumas linhas de orientação para uma pesquisa na Torre do Tombo", Lusitania Sacra, 2a série, v.7 (1995), pp.15180; Pedro Penteado, Arquivos de confrarias e irmandades: alguns pressupostos para o sucesso de uma intervenção arquivística, in: Maria de Lurdes Rosa e Paulo F. Oliveira Fontes (coords), Arquivistica e arquivos religiosos: contributos para uma reflexão (Lisboa: Centro de Estudos de História Religiosa, Universidade Católica Portuguesa, 2000), pp.163-88, <http://repositorio.ucp. pt/bitstream/10400.14/7219/1/HRFS_4_Arquivista\%20e\%20arquivos.pdf $>$; Laurinda Abreu, $O$ Hospício e Irmandade de Nossa Senhora da Piedade, em Évora: uma experiência de reclusão e controlo de pobres em Portugal, S/D, <http://ler.letras.up.pt/uploads/ficheiros/4877.pdf>; Laurinda Abreu, "O papel das Misericórdias dos lugares de além-mar na formação do Império português", História, Ciências, Saúde - Manguinhos, v.8, n.3 (2001), pp.591-611, <http://www. scielo.br/pdf/hcsm/v8n3/7646.pdf>; Isabel dos Guimarães Sá, "Justiça e Misericórdia(s): devoção, caridade e construção do Estado ao tempo de D. Manuel I". Penélope, n.29 (2003), pp.7-31, $<$ http://www.penelope.ics.ul.pt/indices/penelope_29/29_04_ISa.pdf>; Caio César Boschi, Os leigos e o poder: irmandades leigas e politica colonizadora em Minas Gerais, São Paulo, Ática. 1986; Anderson José Machado de Oliveira, "Devoção e caridade: irmandades religiosas no Rio de Janeiro imperial (1840-1889)" (Dissertação de Mestrado, Universidade Federal Fluminense, 1995); Lucilene Reginaldo, Os rosários dos angolas: irmandades de africanos e crioulos na Bahia setecentista, São Paulo, Alameda, 2011; Fritz Teixeira de Salles, Associações religiosas no ciclo do ouro: introdução ao estudo do comportamento social das irmandades em Minas no século XVIII, São Paulo, Perspectiva, 2007; Julita Scarano, Devoção e escravidão: a Irmandade de Nossa Senhora do Rosário dos Pretos no Distrito Diamantino no século XVIII, São Paulo, Nacional, 1978; Maristela dos Santos Simão, As irmandades de Nossa Senhora do Rosário e os africanos no Brasil do século XVIII, Lisboa (Dissertação de Mestrado Universidade de Lisboa, 2010); Mariza de Carvalho Soares, Devotos da cor: identidade étnica e escravidão no Rio de Janeiro, século XVIII, Rio de Janeiro: Civilização Brasileira, 2000; Naiara Ferraz Bandeira Alves, "Irmãos de cor e de fé: irmandades na Parahyba do século XIX" (Dissertação de Mestrado, Universidade Federal da Paraíba, 2006). 
Com a assinatura do Decreto que firmou a separação entre Igreja e Estado (1890) e a Proclamação da República (1889), o Padroado foi abolido. Dentro deste contexto, as reformulações das práticas católicas começaram a fazer sentido, pois a implantação do regime republicano, que se dizia laico, dirigiu para a Igreja Católica a alçada da problemática da sua separação do Estado. Nesse sentido, a necessidade de suscitar condições organizacionais do catolicismo em todas [...] as unidades da federação e articular-se ao poder constituído, no sentido de defender seu patrimônio e conquistar espaços [...], passou a ser estratégia de uma Igreja Católica em plena reforma estrutural. ${ }^{3}$

\section{A Irmandade de Nossa Senhora do Rosário e São Benedito de} Desterro/Florianópolis, cujo primeiro compromisso data de $1750,{ }^{4}$ já realizava suas atividades em período anterior, como indica um documento de $1726 .{ }^{5}$ Percebemos, com base na documentação e bibliografia sobre diferentes irmandades existentes desde o Brasil Colonial, que esta era uma prática comum, pois havia um tempo entre a organização dessas instituições e sua legalização, baseada na aprovação do compromisso. ${ }^{6}$

3 Consultar Michelle Maria Stakonski, Da sacristia ao consistório: tensões da romanização no caso da Irmandade de Nossa Senhora do Rosário e São Benedito dos Homens Pretos - Desterro/Florianópolis (1880-1910), Itajaí: Casa Aberta, 2008, pp.68-9; 109. Para maiores informações, consultar também: Élio C. Serpa, Igreja e poder em Santa Catarina, Florianópolis, Ed. da UFSC, 1997.

4 'Lucas Alexandre Boiteux, nas suas preciosas 'Notas para a História Catarinense', diz que 'com Provisão de 6 de junho dêsse ano (1750) começou a Irmandade do Rosário a erigir uma igreja’, o que evidencia a existência da Irmandade naquela data, com seu Compromisso e a devida aprovação eclesiástica, tanto que se lhe permitia a construção da sua capela. Atendendo a que, na época, os passos para a concessão da aprovação eclesiástica e real bem como para a concessão do compromisso não eram possíveis com grande presteza, demorando sempre as providências e muito mais ainda os transportes, a nossa opinião é que a fundação da Irmandade remonta a época anterior a 1750, pelo menos de um a dois anos" (Oswaldo Rodrigues Cabral, Notícia Histórica da Irmandade de Nossa Senhora do Rosário e São Benedito, Irmandade de Nossa Senhora do Rosário, Florianópolis, 1950, p.3).

5 "Segundo o atual provedor [falecido em 2009], Sr. Oscar Paulo de Souza, a história da primeira capela de Nossa Senhora do Rosário data de antes de 1750. Para ele esta seria a data de fundação da irmandade em caráter oficial, mas a rústica capela já deveria existir desde 1728 pois por determinação do rei de Portugal, o $1^{\circ}$ pároco enviado para o Brasil foi Francisco Justo Santiago, em 1730 e este teria rezado missa na referida capela" (Sandra Makowieck Salles, Débora da Rosa Lima e Marcelo Machado, "As igrejas e capelas de Florianópolis: séculos XVIII e XIX" (Relatório de Pesquisa, Universidade do Estado de Santa Catarina, Florianópolis, 1994).

6 Consultar: Naiara Ferraz Bandeira Alves, "Irmãos de cor e de fé”; Maristela dos Santos Simão, Lá vem o dia a dia, lá vem a Virge Maria. Agora e na Hora de Nossa Morte" - A Irmandade de Nossa Senhora do Rosário e São Benedito dos Homens Pretos, em Desterro (1860-1880), Itajaí: Casa Aberta, 2008; Karla Leandro Rascke, Festas, procissões e celebração da morte na Irmandade de Nossa Senhora do Rosário e São Benedito dos Homens Pretos em Desterro/SC (1860-1890), Itajaí: Casa Aberta, 2010. 
Tal associação, fundada, no século XVIII, por africanos e africanas devotos de Nossa Senhora do Rosário e, em meados do século XIX, de São Benedito, compunha o cenário de uma cidade múltipla, movimentada por diferentes populações e por um porto com grande fluxo de trabalhadores.

Pensar na Desterro do século XIX permite entender quem fazia parte do contingente populacional e, para isso, nos debruçamos um pouco sobre o Relatório apresentado à Assembleia Provincial de Santa Catarina pelo presidente Adolpho de Barros Cavalcanti Lacerda, no ano de 1867, e o Censo de 1872, do qual Fernando Henrique Cardoso (2000) se utiliza para observar a sociedade desterrense daquele período. De acordo com os dados a que Cardoso recorreu, a freguesia de Desterro tinha, em 1866, 4.361 brancos, $1.275 \operatorname{pretos}^{7}$ e 838 pardos; em 1872, havia 5.884 brancos, 1.910 pretos e 1.296 pardos. ${ }^{8}$ Tais números nos permitem considerar que a população afrodescendente nos dois períodos chegava, respectivamente, a 32,64\% e 35,27\%. Tais números apresentam indícios significativos da presença de origem africana numa cidade localizada ao sul do Brasil, marcada na memória hegemônica da região como branca e europeia.

$\mathrm{Na}$ periferia da cidade, localizavam-se os bairros habitados por pessoas mais pobres, geralmente de origem africana: a Figueira, a Tronqueira, a Pedreira, o Beco do Sujo, o Toca, o Campo do Manejo e a Cidade Nova. Segundo Silva, o bairro da Figueira, possivelmente o maior, era considerado um "antro de prostituição", muito frequentado por marinheiros, habitado por pessoas extremamente humildes. Situado a oeste do centro histórico de Florianópolis, possuía trapiches, estaleiros, armazéns, inúmeras casas de negócios, hotéis, padarias, boticas, o que, segundo Cardoso, "transformou a região em uma ativa zona produtiva e,

Segundo trabalho de Mattos, interpretação incorporada também por Cardoso, ao pensar as populações de origem africana em Desterro no século XIX: a cor estava associada à condição social do indivíduo. Portanto, no entendimento de Mattos e Cardoso: mulato era a pessoa de origem africana de pele clara; o termo pardo significava o escravo descendente de homem livre (branco) ou nascido livre, mas com as marcas da ascendência africana; preto designava a origem africana; crioulo era o escravo nascido no Brasil. "Já a palavra 'negro' designava sempre a condição cativa do indivíduo". Consultar: Paulino de Jesus Francisco Cardoso, Negros em Desterro: experiências das populações de origem africana em Florianópolis na segunda metade do século XIX, Itajaí: Casa Aberta, 2008; Hebe Maria Mattos, Das cores do silêncio: os significados da liberdade no Sudeste escravista, Brasil século XIX, Rio de Janeiro: Nova Fronteira, 1998.

8 Fernando Henrique Cardoso, Negros em Florianópolis: relações sociais e econômicas, Florianópolis: Insular, 2000, p.136. 
ao mesmo tempo, atraiu centenas de miseráveis de todos os matizes em busca de trabalho e moradia. Era uma área ativa e perigosa, onde nem mesmo as forças de segurança pareciam estar a salvo". ${ }^{9}$

Nessa área movimentada e central, localizava-se a capela da Irmandade de Nossa Senhora do Rosário e São Benedito, cuja construção da igreja, como ressaltou Oswaldo Rodrigues Cabral, resultou de árduos dias de trabalho e dedicação de muitos cativos, livres e libertos que, nos dias santificados e domingos, planejavam e executavam as obras da capela. De acordo com os livros-caixas e as atas, foram constantes as obras, os reparos, as reformas. Nesses documentos, encontramos itens que fizeram parte das despesas da capela durante praticamente todo o século: pedra, cal, vidros, pregos, tijolos, tábuas, telhas, e outros utensílios e materiais. Além disso, era recorrente o pagamento de pessoas para a execução de serviços, tanto das obras como da conservação do local. Desse modo, além de reformar, era preciso manter o local asseado, capinado, pintado, limpo.

A edícula foi construída na antiga Rua do Rosário, hoje Rua Marechal Guilherme, próximo da igreja matriz da cidade de Florianópolis. A iniciativa da construção da atual igreja surgiu em fins do século XVIII. "Só em 1787, entretanto, chegou ao Destêrro a licença do Bispo do Rio de Janeiro para a construção da nova Igreja". As obras foram lentas. "Em [17]92, sete anos depois de iniciadas, foi que a Mesa pôde determinar fazer o madeiramento para faixar a nova Capela e juntamente feixar o arco da mesma com tijolo singelo". ${ }^{10}$ As imagens de santos existentes na capela antiga, que naquele ano fora demolida, destinou-se à igreja matriz, onde ficariam abrigadas até que as obras da nova capela findassem. Longos anos... Segundo Cabral, "ao raiar do século XIX, não estava ainda a nova igreja concluída", "entretanto, em 1800, já se encontra notícia da tradicional missa de 26 de dezembro, embora ainda sem as solenidades que haviam marcado época em outros tempos, isto é, sem cantos e sermão". ${ }^{11}$

Cardoso, Negros em Desterro, p.69.

10 Cabral, "Notícia histórica", pp.7-8.

11 Cabral, "Notícia histórica", p.9. 
A capela da irmandade compunha o cenário movimentado da cidade de então, em fins do século XIX, ainda denominada Desterro. ${ }^{12}$ As reformas urbanas da capital, já Florianópolis, ocorreram efetivamente na Primeira República, sendo a nova elite republicana responsável pela remodelação de espaços e práticas urbanas. ${ }^{13} \mathrm{~A}$ "picareta modernizadora" empurrou afrodescendentes, ${ }^{14}$ pobres e desvalidos para as periferias da cidade, "especialmente com a abertura da Avenida Hercílio Luz, que delimitou a segregação espacial e provocou o início da ocupação dos morros adjacentes ao centro urbano". ${ }^{15}$

\section{Um funeral "digno": sinos, velas, cortejo... e missas pela alma}

Nos dizeres de João José Reis, a "boa morte significava que o fim não chegaria de surpresa para o indivíduo", que sua alma estivesse pronta para a "partida", com todos os direitos ao cortejo fúnebre que lhe coubesse e que seus irmãos e irmãs pudessem proporcionar. Participar de uma irmandade também significava contar com socorro na hora da morte, seja de seus parentes ou de si próprio, desde que arcassem com os devidos gastos. Apenas para os filiados muito pobres e incapazes de arcar com o funeral, abriam-se exceções. ${ }^{16}$

$\mathrm{O}$ medo de ter o corpo insepulto ou ser sepultado sem honra fez

12 A cidade passou a se chamar Florianópolis a partir de 1894.

13 Norberto Dallabrida, A fabricação escolar das elites: o Ginásio Catarinense na Primeira República, Florianópolis: Cidade Futura, 2001, p.59.

14 Trabalhamos com a noção de afrodescendentes ou populações de origem africana, não no sentido de uma raça, mas enquanto grupos populacionais com suas perspectivas de cultura, na tentativa de fugir dos "pesos" que termos como "negro" pode carregar enquanto uma identidade entre pessoas das mais variadas origens e experiências, possível homogeneidade e ideologia, o que não nos cabe trazer neste texto. Percebemos, nos irmãos e irmãs do Rosário que vivenciaram o espaço urbano de Florianópolis, muitos "dissabores" entre si, acontecimentos que nos permitem interpretar diversidades e dinâmicas de identificação. Ao pensar em populações de origem africana, despertamos para possibilidades mais amplas, podendo inserir e tentar vislumbrar diferentes povos e experiências. Consultar: Cardoso, Negros em Desterro; Antonio Sérgio Alfredo Guimarães, "Notas sobre raça, cultura e identidade na imprensa negra de São Paulo e Rio de Janeiro, 1925-1950", Revista Afro-Ásia, n.29/30 (2003), pp.247-69.

15 Dallabrida, A fabricação escolar das elites, p.61.

16 João José Reis, A morte é uma festa: ritos fúnebres e revolta popular no Brasil no século XIX, São Paulo: Companhia das Letras, 1991. 
com que pretos quisessem um funeral cristão. Dessa forma, não apenas o morto recebia uma morte digna, mas também a irmandade mostrava sua pompa e os cuidados com seus mortos. ${ }^{17}$ Era costume, até o século XIX, enterrarem-se os mortos nas igrejas, capelas e demais lugares "santos", pela proximidade que acreditavam existir com a salvação. Assim, quanto mais próximo ao altar, maiores as "garantias" de ter a alma salva. Nas mais diferentes regiões do país, encontram-se informações sobre tais práticas e isso não foi muito diferente na Irmandade do Rosário de Desterro/Florianópolis.

No entendimento de Reis, esse caráter leigo compunha um jeito de compreender a morte e seus rituais pela "pompa", no chamado catolicismo barroco, caracterizado por um desejo de externar práticas devocionais em ritos de passagem como indicativo de fé e renovação da vida.

O funeral barroco se caracterizava pela pompa: o luxo dos caixões, dos panos funerários, a quantidade de velas queimadas, o número de participantes no cortejo - de padres, pobres, confrarias, músicos, autoridades, convidados - , a solenidade e o número das missas de corpo presente, a decoração da igreja, o prestígio do local escolhido para sepultura. ${ }^{18}$

A cultura católica ocidental, desde a Idade Média até a Idade Moderna, tinha na procissão fúnebre uma demonstração de brilho, suntuosidade, elementos que chamassem a atenção, uma cerimônia composta por música, muitas pessoas e a condução do corpo até seu destino final. É interessante refletir sobre os panos funerários e o cuidado com a "pompa". Nas tradições africanas, famílias confeccionam panos para a morte de seus parentes até hoje. ${ }^{19} \mathrm{O}$ catolicismo praticado por essas populações deve ser considerado particular, próprio, repleto de significados complexos diferentes do que outros grupos culturais experienciavam enquanto católicos.

17 Reis, A morte é uma festa, p.92; Mariza de Carvalho Soares, "Escravidão africana e religiosidade católica (Rio de Janeiro, século XVIII)" (trabalho apresentado ao Prêmio Silvio Romero, 1999, p.142.

18 Reis, A morte é uma festa, p.75.

19 Reis, A morte é uma festa; Cláudia Rodrigues, Lugares dos mortos na cidade dos vivos: tradições e transformações fúnebres no Rio de Janeiro, Rio de Janeiro: Secretaria Municipal de Cultura, 1997; James H. Sweet, Recriar África: cultura, parentesco e religião no mundo afro-português (1441-1770). Lisboa: Edições 70, 2007. 
Essa forma de compreensão do catolicismo praticada por populações de origem africana, um catolicismo dinâmico, inserido em universos culturais de matrizes africanas, também implicou formas diferenciadas de lidar e sentir a morte, por mais que as práticas fossem denominadas católicas. "A força das releituras negativas sobre os cultos africanos marcaram as trajetórias de muitos indivíduos que precisaram encontrar mecanismos para, ao mesmo tempo, manter os cultos afro-ancestrais e professar a religião socialmente aceita", o catolicismo. ${ }^{20}$

Discutindo as apropriações da morte católica por africanos e afrodescendentes no Rio de Janeiro setecentista, Cláudia Rodrigues apresenta indicativos da presença de elementos herdados das concepções africanas no que tange às práticas católicas, em especial como as concepções e representações sobre a morte impactaram as vivências católicas de africanos e seus descendentes. ${ }^{21}$ A partir do estudo de testamentos de homens e mulheres de origem africana, a autora percebeu os cuidados e as práticas envolvidas na obtenção da salvação ou, pelo menos, no anseio pela salvação. Chama a atenção para o fato de que muitos elementos apontam para a convivência entre representações católicas e africanas na hora da morte. Ou, como bem ressalta, "por algum motivo, fizeram questão de se apresentar como sabedores de que precisavam se mostrar contritos na iminência da morte". ${ }^{22}$

Ao analisar experiências associativas de africanos e seus descendentes na Bahia, em Portugal e em Angola, Lucilene Reginaldo também registrou que a "manutenção destes espaços permitiu a criação de práticas e vivências do catolicismo imbuídas de valores e representações africanas". ${ }^{23}$ No caso da região centro-africana, a autora destaca que o catolicismo não significou abandono de práticas tradicionais, pois a "poligamia e os cultos tradicionais foram fontes inesgotáveis de conflitos

20 Mara Regina do Nascimento, "Irmandades leigas em Porto Alegre: práticas funerárias e experiência urbana (séculos XVIII e XIX)" (Tese de Doutorado, Universidade Federal do Rio Grande do Sul, 2006), p.109, <http://www.lume.ufrgs.br/bitstream/handle/10183/8574/000581308. pdf? sequence $=>$.

21 Cláudia Rodrigues, "Apropriações da morte católica por africanos e seus descendentes no Rio de Janeiro setecentista", Cadernos de Ciências Humanas - Especiaria, v.10, n.18 (2007), pp.427-67.

22 Rodrigues, "Apropriações da morte", p.443.

23 Reginaldo, Os rosários dos angolas, p.23. 
entre os convertidos centro-africanos e missionários de várias épocas". ${ }^{24}$ Abordando vivências culturais de africanos e seus descendentes na Bahia, em especial organizados em irmandades, a autora acrescenta que ritmos, danças, palmas, cantos e muitas formas coletivas de celebração eram marcantes em acontecimentos das irmandades, como apresentam inúmeros relatos de viajantes e documentos oficiais. ${ }^{25}$

Tanto culturas africanas quanto católicas preocupavam-se com a morte, sendo diferenciadas, no entanto, suas concepções com relação a esse momento de passagem. Possuindo visões de mundo distintas, suas relações com os mortos e a própria ideia de morte, de antepassados e tradições, constituíam-se de perspectivas diversas. As experiências relacionadas com a morte por parte das populações de origem africana em Desterro/Florianópolis permitem conhecer códigos culturais presentes nessas populações entre o final do século XIX e as primeiras décadas do $\mathrm{XX}$, época de interferências do catolicismo romanizado ${ }^{26}$ e tensões entre associações religiosas de caráter leigo e a Igreja Católica. ${ }^{27}$

O catolicismo romanizado trouxe padres de origem europeia para as paróquias de Santa Catarina, em especial muitos germânicos

24 Reginaldo, Os rosários dos angolas, p. 39 .

25 Reginaldo, Os rosários dos angolas.

26 O período de fins do século XIX foi marcado pelo catolicismo romanizado ou ultramontano, ação impetrada pela Igreja Católica a fim de controlar os costumes do catolicismo dito tradicional (leigo) praticado, em especial, pelas irmandades. O poder religioso, na ótica desse catolicismo, concentrava-se nas mãos do clero, tendo os leigos, perda na autonomia e gestão das associações nas quais atuavam como dirigentes. De acordo com Michele Maria Stakonski, "essa estrutura devocional católica contava com pouquíssimos padres que lhes davam assistência. Em Santa Catarina, o catolicismo sustentou-se por iniciativa de poucos padres e muitos leigos nas direções de irmandades e confrarias católicas. Os primeiros resquícios de catolicismo romanizado foram introduzidos inicialmente nas áreas de imigração europeia na segunda metade do século XIX, pelos próprios imigrantes e pelos sacerdotes que lhes davam assistência religiosa" (Stakonski, "Da sacristia ao consistório", p.97).

27 Segundo Riolando Azzi, o catolicismo tradicional ou barroco constitui-se baseado no caráter leigo, popular e com manifestações públicas de fé, em geral, sem muitos "controles" ou regulamentos sobre essas práticas devocionais, o que muitas vezes era visto pela Igreja como profanidade. Como o próprio autor destaca, esse catolicismo dito tradicional, popular é leigo, medieval, luso-brasileiro, familiar e social, comporta compreensão limitada, pensada apenas a partir dos parâmetros oriundos de influências lusas, com alguns indícios de elementos indígenas e africanos, restringindo a compreensão, por exemplo, de todas as manifestações de reisados e festas com ritmos, cores, performances e instrumentos africanos ou de origens africanas. Ver: Riolando Azzi, "Elementos para a história do catolicismo popular", Revista Eclesiástica Brasileira, v.36, n.141 (1976). 
que atuaram na Primeira República, envolvendo a Igreja Católica em reformas em sua estrutura, tornando-a uma forte instituição disciplinar. A germanização do clero acarretou maior rigidez no controle das práticas dos devotos, incidindo também nas manifestações devocionais mágico-religiosas, presentes em especial nas irmandades.

Nos séculos XVIII e até as primeiras décadas do XIX, era comum, em Desterro, o enterro de corpos envoltos em mortalhas, prática também existente em outras regiões brasileiras. ${ }^{28}$ No caso de Salvador, Reis explorou o significado social e cultural do uso das mortalhas; cores diferenciadas e invocações a santos compunham inúmeros repertórios no momento da morte, em especial a intercessão solicitada a esses santos quando ocorresse a partida. ${ }^{29}$ As vestimentas funerárias demonstravam um tipo de preocupação com a morte e, em muitos casos, as melhores roupas tidas em vida eram utilizadas para o enterramento. Segundo Cláudia Rodrigues, para os "cristãos, o objetivo era obter a salvação. Quanto aos africanos, tratava-se de se preparar para o encontro com os ancestrais". ${ }^{30}$ Nesse sentido, o uso de mortalha indicava que a alma, ao se desprender do corpo no mundo dos vivos, não ficaria vagando pela Terra. Além da mortalha, o corpo era depositado numa espécie de rede, e algumas irmandades utilizavam esquifes para carregar os corpos, um tipo de armação de madeira forrada, como se fosse uma padiola. ${ }^{31}$

Quase em meados do século XIX, apareceram os primeiros caixões para condução dos corpos aos seus destinos, sem que houvesse, no entanto, exclusividade, sendo utilizados basicamente como transporte do cadáver. Assim, o corpo era conduzido e, após ser sepultado, o caixão retornava ao seu local de origem — uma irmandade ou instituição — à

28 Em trabalho sobre o cemitério dos "pretos novos", Júlio César Medeiros da Silva Pereira busca "desvelar práticas funerárias africanas" que possibilitem compreender os motivos pelos quais cativos se filiavam às irmandades, visto que muitos encontravam nessas associações uma forma de garantir enterro digno, um sepultamento. "Cientes do falecimento de um irmão, caberia à irmandade encomendar o corpo, preparar a mortalha adequada, o transporte e o sepultamento com a presença de um religioso, assim como a missa e as velas" (Júlio César Medeiros da Silva Pereira, À flor da terra: o cemitério dos pretos novos no Rio de Janeiro, Rio de Janeiro: Garamond/IPHAN, 2007, p.54).

29 Reis, A morte é uma festa, pp.118-9.

30 Rodrigues, Lugares dos mortos, p.196.

31 Oswaldo Rodrigues Cabral, Nossa Senhora do Desterro. Notícia I, Florianópolis: Editora da UFSC, 1971, p.503. 


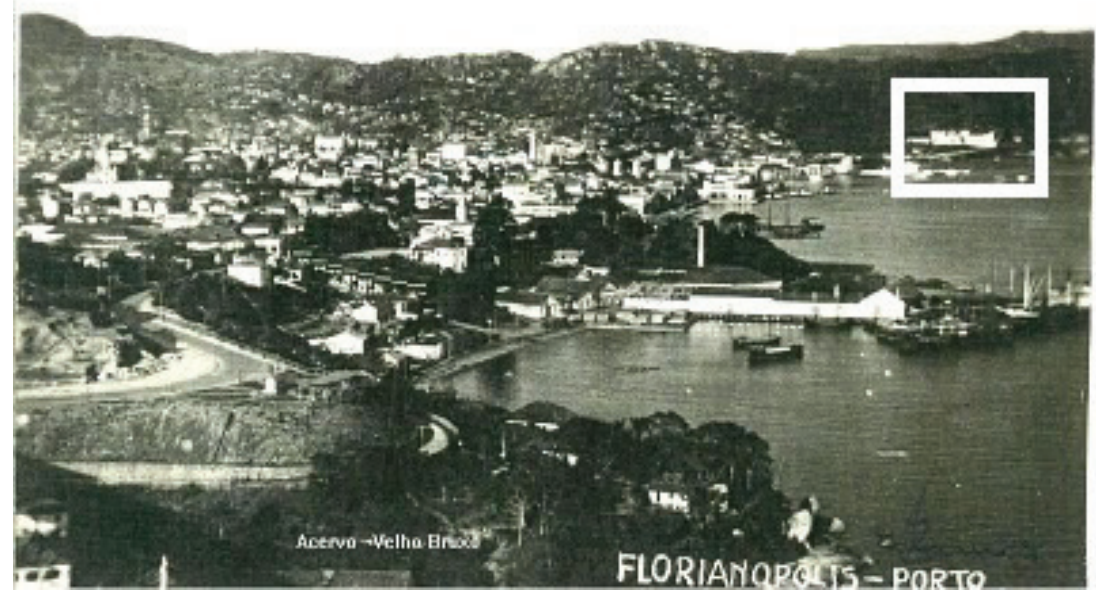

Figura 1 - Vista do centro da torre da ponte Hercílio Luz (1945).

Destaque em realce branco para o Hospital de Caridade

Fonte: Acervo Velho Bruxo <http://hid0141. blogspot.com.br/2010/12/florianopolis-antigo.html>, acessado em 25 de fevereiro de 2013.

qual pertencesse. Nessa época, era muito comum que as associações alugassem os caixões para quem os necessitasse. Inicialmente, ser conduzido num caixão era sinal de status, mas, com o passar do tempo, essa prática se popularizou, e até os mais pobres acessavam este "conforto" na hora da morte. ${ }^{32}$

Nas palavras de André Luiz Santos, quem estivesse no porto ouviria os sinos das igrejas anunciando um cortejo que se aproximava. "Os mortos eram carregados em caixões abertos ou nos esquifes das Irmandades. [...]. Os defuntos escravos ou crianças abandonadas eram carregados de qualquer jeito, sem caixão". ${ }^{33}$ Essa descrição apresentada por Santos refere-se aos corpos de mortos no Hospital de Caridade, ou com enterro sob a responsabilidade do hospital. Esses dados permitem imaginar, por exemplo, o deslocamento necessário do Hospital de Cari-

32 Cabral, Nossa Senhora do Desterro, p.503.

33 André Luiz Santos, "Do mar ao morro: a geografia da pobreza urbana em Florianópolis" (Tese de Doutorado, Universidade Federal de Santa Catarina, 2009), p.354. 
dade até o Cemitério Municipal, então localizado na cabeceira da atual Ponte Hercílio Luz. Além disso, o trajeto, bastante longo e feito pelas ruas da cidade, com soar de sinos, não passaria despercebido. A Figura 1 apresenta um indicativo da distância entre o hospital e o cemitério. A localização do cemitério em relação ao Hospital de Caridade e à Irmandade do Rosário demandavam, assim, um longo deslocamento em diferentes ruas para realização dos enterramentos.

O primeiro Cemitério Público de Desterro foi construído em 1841, numa região mais afastada do centro da cidade, no terreno que hoje aloca o Parque da Luz, nas proximidades da cabeceira da Ponte Hercílio Luz. Sua instalação, no alto do morro, logo na entrada da cidade, aos olhos de todos, foi alvo dos higienistas e urbanistas no começo do século XX, quando estavam a pleno vapor as obras de reforma da cidade. O cemitério interrompia o caminho de passagem da ponte, cuja construção seria iniciada em 1923. ${ }^{34}$ Assim, o cemitério foi transferido para a região de Itacorubi.

A localização de cemitérios esteve entre os pontos de tensão na história das cidades, em especial com as ações do higienismo e da medicalização da sociedade. No entendimento de Mara Regina do Nascimento, que discutiu o processo de transferência do cemitério na cidade de Porto Alegre em meados do século XIX, as reformas nas cidades e as intenções de "alargamento" do território promoveram uma ampliação no espaço e um distanciamento de determinados ambientes da cidade para zonas mais afastadas do perímetro urbano, de maior circulação de pessoas. ${ }^{35}$ No caso de Desterro/Florianópolis, quando o cemitério foi construído em 1841, a região era afastada do centro da cidade, um local de pouca circulação de pessoas e quase sem residências nas proximidades. No entanto, ao longo das décadas, a situação se alterou, e as demandas por modificações foram surgindo, culminando na mencionada transferência.

Em 3 de setembro de 1888, a Assembleia Provincial de Santa Catarina, em sessão ordinária, discutiu a questão do cemitério público,

\footnotetext{
34 Elisiana Trilha Castro, "Aqui jaz um cemitério: a transferência do cemitério público de Florianópolis (1923-26)" (Trabalho de Conclusão de Curso, Universidade do Estado de Santa Catarina, 2004), p.13.

35 Nascimento, "Irmandades leigas em Porto Alegre", p.312.
} 


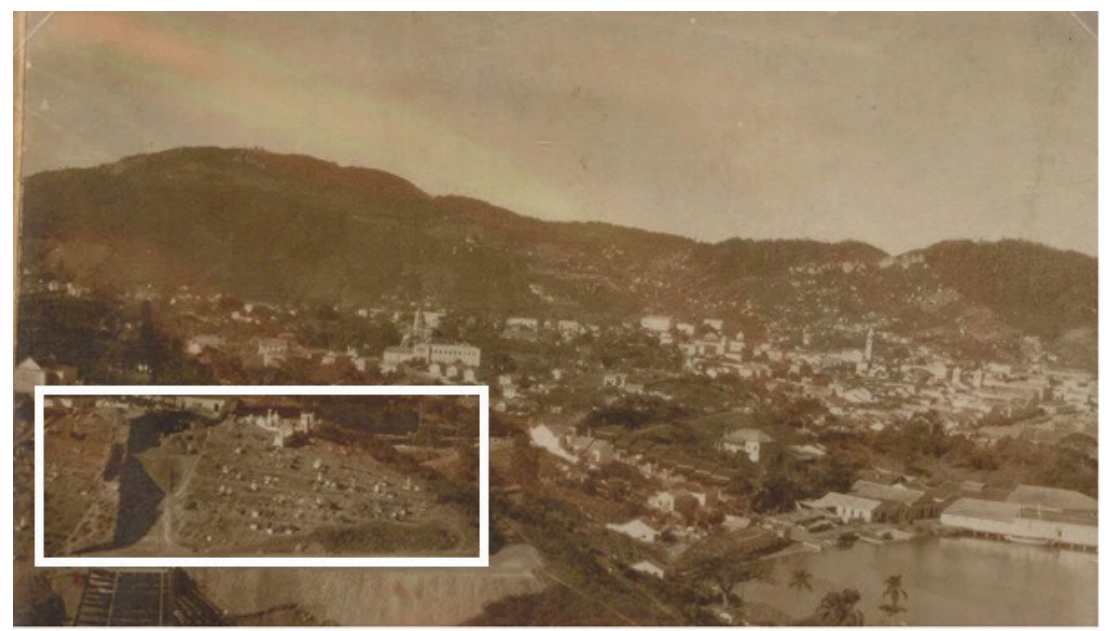

Figura 2 - Vista parcial de Florianópolis, 1920. Destaque em realce branco para o cemitério localizado na cabeceira da Ponte Hercílio Luz Fonte: Acervo do Instituto Histórico e Geográfico de Santa Catarina.

informando sobre seu terreno e a divisão entre as irmandades e demais associações. A preocupação com a morte, os enterramentos e as condutas para os rituais eram manifestações e cuidados efetivos de leigos, mas também estavam sob os olhares da administração provincial.

A figura 2, fotografia da década de 1920, permite perceber a localização do cemitério e como estava construído. O espaço também foi utilizado pelos protestantes para construção de um cemitério, ao lado do municipal, visto que eram proibidos pela Igreja Católica de serem enterrados em cemitérios católicos. ${ }^{36} \mathrm{~A}$ ideia de transferir os enterros para o cemitério foi planejada e sua concretização distanciada do perímetro urbano da cidade. O lugar atendia ao pensamento da época com relação a cemitérios: "terreno [...] enxuto, longe dos rios, e ajuntamento de aguas; bastantemente vasto, para dar lugar a todos os corpos, durante quatro anos pelo menos, sem se bulir no lugar das primeiras covas". ${ }^{37}$

36 Para maiores informações a respeito, consultar: Elisiana Trilha Castro, Um chão para cair morto: os cemitérios de imigrantes protestantes em Santa Catarina no século XIX, Florianópolis, 2009, p.4, <http://elisianacastro.files.wordpress.com/2009/06/artigo-elisiana-siepea.pdf >, acessado em 15 de dezembro de 2012.

37 Biblioteca Nacional, Jornal Aurora Fluminense, n.145 de 23/1/1829. "Sobre o depósito de pretos novos e a necessidade de um cemitério" apud Pereira, À flor da terra, p.95. 
As mudanças no cuidado com o enterro de mortos, em especial pobres e cativos, às vezes enterrados "à flor da terra", ou seja, em covas rasas, também influenciou, de modo geral, no Brasil, a questão de onde inumar os corpos e como fazê-lo.

Até 1840, quando foi proibido, o sepultamento dos membros da irmandade era feito na própria capela da associação. "O alto da colina do estreito entre a Ilha e o continente no terreno da chácara de José Vieira de Castro foi o lugar escolhido para o cemitério". Cada irmandade e associação religiosa de Desterro adquiriu uma área específica, indicada por uma cruz de ferro. ${ }^{38} \mathrm{O}$ jornal $A$ Regeneração noticiou a decisão adotada pela Assembleia com relação ao cemitério: "as irmandades e particulares, que possuam qualquer porção de terreno no atual cemitério público, terão direito a igual porção em o novo cemitério, independente de qualquer pagamento". ${ }^{39}$

O Cemitério Público no Morro do Vieira, a caminho do Estreito, atualmente cabeceira da Ponte Hercílio Luz, foi o espaço destinado ao sepultamento dos mortos. No entanto, nem todos poderiam ser enterrados naquele espaço, pois quem não proferisse a fé católica ou assim se afirmasse corria o risco de ficar insepulto, visto que protestantes eram proibidos pela Igreja Católica de ser sepultados em cemitérios católicos. ${ }^{40}$ Assim, em terreno comprado ao lado do Cemitério Público, instalou-se o Cemitério Alemão, em que se sepultariam protestantes e outros. Por terem sido descobertos protestantes, foram expulsos da irmandade José Epiphanio da Cunha, excluído em 1899, Justo Mario da Costa, em 1897, e Roza Camara da Cunha, em $1899^{41}$ e não teriam destino certo quando a morte lhes acometesse. O Cemitério Alemão, embora particular, destinou-se, também, a atender tais demandas.

38 Santos, "Do mar ao morro", p.204.

39 Ata da $2^{\text {a }}$ Sessão Ordinária da Assembleia Provincial de Santa Catarina. Jornal A Regeneração, 07 de setembro de 1888, n.188, Desterro. Acervo da Biblioteca Pública do Estado de Santa Catarina, Setor de Obras Raras.

40 Para maiores informações a respeito, consultar: Elisiana Trilha Castro, Um chão para cair morto: os cemitérios de imigrantes protestantes em Santa Catarina no século XIX, Florianópolis, 2009, p.4, <http://elisianacastro.files.wordpress.com/2009/06/artigo-elisiana-siepea.pdf >, acessado em 15 de dezembro de 2012.

41 Tabela de Registro de Irmãos (1816 a 1937). Acervo da Irmandade de Nossa Senhora do Rosário e São Benedito. 
Vale indagar se o cemitério, construído ao lado do municipal, demonstrava uma tensão presente entre católicos e protestantes na cidade, resvalando nos membros da irmandade, mais assiduamente vislumbrados pela Igreja, evitando que "seitas" proibidas permeassem o universo da associação. Os protestantes excluídos talvez indiquem uma disputa existente na cidade com relação a um "mercado de almas", sendo possível uma perda de "domínio" da Igreja Católica. O cemitério dos alemães, como ficou conhecido, relacionado com os casos de expulsão de protestantes da Irmandade de Nossa Senhora do Rosário e São Benedito, permite-nos conjeturar que a presença de protestantes e adeptos estava em expansão na cidade, acompanhando a ampliação de novas elites e o projeto político. Nesse sentido, as antigas elites portuguesas, suplantadas por elites de origem germânica em fins do século XIX e primeiras décadas do XX, iniciaram um novo modo de compreensão da cidade e um projeto, um reordenamento da estrutura urbana e a tentativa das elites locais de "forjá-la como modelo de uma urbe moderna", de acordo com os sonhos da República. ${ }^{42}$

A questão de onde enterrar os mortos sofreu grandes interferências, tanto da Igreja Católica quanto das pressões e ideias político-sanitárias, ${ }^{43}$ e os elementos presentes nos enterros ocidentais possuem as marcas dessas influências, ocorridas, em grande medida, ao longo do século XIX: afastamento do cemitério do espaço urbano, caixões individuais, túmulos separados e lacrados, prazo limite para enterro do morto, evitando-se possíveis contágios, entre outras.

Até meados da década de 1880, Desterro havia se alarmado com as inúmeras epidemias. Uma das questões que nos chamou atenção foi a alteração na forma de condução dos corpos de mortos vítimas dos contágios. A inspetoria da cidade recomendou "que os mortos por varíola

${ }^{42}$ Para maiores informações sobre essas alterações na conjuntura política da cidade e as tensões políticas oriundas dessa modificação nos grupos das elites dirigentes, consultar: Dallabrida, $A$ fabricação escolar das elites; Cardoso, Negros em Desterro.

43 "A partir da segunda metade do século XIX torna-se consenso entre as autoridades médicas e governamentais de várias cidades brasileiras a necessidade da exclusão dos cemitérios do perímetro urbano, inclusive os cemitérios contíguos às igrejas, devido ao fato de serem facilitadores da propagação dos miasmas culpados pelas epidemias. Começa, então, a criação de cemitérios extra-muros [...]". Consultar: Edna Teresinha Rosa, "A relação das áreas de cemitérios públicos com o crescimento urbano" (Dissertação de Mestrado, Universidade Federal de Santa Catarina, 2003), p.33. 
fossem conduzidos até o cemitério em carroças fechadas e sem acompanhamento, revela[ndo] a dimensão e o extremo das medidas para combater a epidemia de $1882 " .{ }^{44} E$ É interessante estabelecer relação entre esse surto epidêmico de varíola e o relatado por Jucieldo Ferreira Alexandre no Cariri (CE), que envolvia o cólera. Tais surtos provocaram alterações nas práticas funerárias, por envolverem uma enorme quantidade de mortes repentinas, quase ao mesmo tempo e a urgência dos enterros. Nesse sentido, como ressaltou Alexandre, a intenção era "colocar os mortos o mais longe possível", sendo que algumas diferenciações indicavam os status dos mortos, como o caso de pessoas abastadas serem carregadas em caixões fechados, e os pobres em pequenas redes atravessadas por varas. ${ }^{45}$ No entanto, apesar dessas diferenças na condução do corpo, a urgência da epidemia implicava que muitos mortos "partissem" sem receber a encomendação da alma, um dos ritos necessários a uma boa morte. ${ }^{46}$

No caso de Desterro/Florianópolis, a experiência com epidemias que haviam levado centenas de pessoas à morte, a cada momento que um novo surto se estabelecia na cidade, gerou medidas preventivas. Uma delas implicou alterações emergenciais nas práticas funerárias. Em se tratando de uma epidemia, o corpo do morto era conduzido em uma carroça lacrada, evitando possíveis contaminações. Como a irmandade conduziu seus funerais diante da impossibilidade de fazer o cortejo pela Rua do Príncipe até o cemitério? Nesses casos, talvez o enterro digno ficasse desprovido de cortejo adequado. São apenas ilações, visto não termos dados suficientes para afirmar se associados da irmandade vieram a óbito em virtude das endemias e quais os procedimentos tomados pelos irmãos e irmãs diante disso.

Desde o Código de Posturas de 1845, as preocupações com os cortejos fúnebres e os caixões para condução dos mortos estavam sob a mira das autoridades. $\mathrm{O}$ alvo principal eram as irmandades e suas práticas - as irmandades católicas utilizavam, nos cortejos, esquifes abertos, o

\footnotetext{
44 Santos, "Do mar ao morro", pp.379-80.

45 Jucieldo Ferreira Alexandre, "Quando o 'anjo do extermínio' se aproxima de nós: representações sobre o cólera no Semanário Cratense O Araripe (1855-1864)" (Dissertação de Mestrado, Universidade Federal da Paraíba, 2010).

46 Reis, A morte é uma festa.
} 
que permitia certa exposição do corpo: aos olhos preocupados das autoridades com as epidemias, a prática deveria ser extinta, passando-se a utilizar caixões fechados.

Nenhum corpo de qualquer tamanho, e cor que seja será conduzido a sepultura sem ser em caixão fechado, quando qualquer Facultativo tiver declarado que a enfermidade do falecido fora contagiosa. A administração da Caridade terá um, ou mais caixões, que servirão de conduzir os cadáveres [...] Ficam extintos os Esquifes das Irmandades, e substituídos por caixões fechados $[\ldots]^{47}$

O medo, principalmente da varíola, constituiu preocupação do Governo com as medidas sanitárias e os cuidados com a higiene, assim como intensificou a fiscalização sobre residências, lixo, águas servidas e a própria condução da morte por parte das associações. O receio de uma nova epidemia chegou ao extremo de proibir os "cortejos fúnebres que atravessassem áreas habitadas". ${ }^{48}$ A morte envolvia diferentes instâncias, para além do sagrado e dos preparativos de cada sociedade em relação a ela.

A Irmandade de Nossa Senhora do Rosário e São Benedito, ainda denominada dos Homens Pretos até 1905, recebeu influências das alterações sanitárias e da Igreja, necessitando realizar mudanças em suas práticas para adequar-se às novas regras mortuárias em vigência a partir de 1845, especialmente quando os Códigos de Postura, baseados nas preocupações médico-sanitaristas e higienistas, exigiam modificações para evitar contágios. ${ }^{49}$

47 ALESC, Código de Posturas de Desterro de 1845. Capítulo Segundo, Artigo 9, p.211. Lei n.222 de 10 de maio de 1845. Arquivo Histórico da Assembleia Legislativa/SC

48 Santos, "Do mar ao morro", p.372.

49 Aliada aos cuidados sobre a localização do cemitério, lugar por onde poucas pessoas transitavam ou em cujos arredores poucos moravam, a região da atual cabeceira tornou-se ideal segundo médicos higienistas e políticos. Desterro sentiu os horrores das epidemias na segunda metade do século XIX. A população foi acometida, entre 1840 e 1841, por "febres cerebrais", deixando muitas vítimas, em especial militares. "No primeiro ano dessa epidemia o Cemitério do Estreito foi inaugurado e foram proibidos os enterramentos nas Igrejas da cidade". "Esses anos de epidemias devem ter influenciado o código de posturas da cidade aprovado em 1845, quanto ao conjunto de medidas médicas sobre higiene e saúde e as medidas de sanidade urbana que o código continha. Um longo período de epidemias de 'febres escarlatina e amarela' assolou a província durante os anos de 1850 até 1853. Segundo Almeida Coelho (1877, p.178 e 179), mais de um terço da população de Desterro foi atingida, o que fez diminuir a população. A febre causou grande mortalidade no colégio dos padres jesuítas, o que, segundo Almeida, foi a causa do fim do estabelecimento na província" (Santos, "Do mar ao morro", p.356). 
A mudança de local do Morro do Vieira para o Itacorubi envolveu muitos aspectos, dentre os quais, a divulgação em jornais informando que a municipalidade solicitava que os responsáveis pelos corpos sepultados no cemitério que funcionara desde 1841 fizessem a exumação dos cadáveres e providenciassem a transferência para o novo local. $\mathrm{O}$ espaço em que se situava o então cemitério fazia parte de novos interesses políticos, pois seria destinado à construção da Ponte Hercílio Luz, que ligaria o continente à ilha de Santa Catarina, possível apenas por barco ou balsa. Dada a urgência em construir esse acesso mais facilitado à ilha e condizente com o processo de automobilização ocorrido em inícios do século XX, medidas foram encaminhadas pela administração da cidade, inclusive a retirada do cemitério do espaço central da cidade.

Publicou-se, então, em 25 de setembro de 1924, um edital com prazo de sessenta dias para as providências cabíveis de remoção dos corpos. Caso os familiares não cumprissem essa obrigação, as exumações seriam feitas pelo município. ${ }^{50}$

A reserva de áreas dentro do cemitério São Francisco de Assis para as sete irmandades tem raízes históricas no século XIX quando da construção do Cemitério Público no Morro do Vieira. As irmandades receberam, por volta de 1841, da Câmara municipal de Desterro áreas demarcadas dentro do cemitério para as suas necrópoles, já que haviam sido proibidos os enterramentos dentro e ao redor das igrejas. Diferentemente, a pequena comunidade alemã da cidade, quase todos comerciantes protestantes, por sentir-se depreciada pelo tratamento recebido pela comunidade católica, que lhes reservava espaços dentro dos cemitérios destinados aos indigentes, decidiu comprar um terreno ao lado da necrópole pública de uso restrito aos seus associados no Morro do Vieira, hoje cabeceira insular da Ponte Hercílio Luz. Interessada na desativação do Cemitério Público, a Prefeitura da capital ofereceu, em 1925, às irmandade e a Associação da Comunidade Alemã áreas dentro do extenso Cemitério São Francisco de Assis, onde permanecem até hoje..$^{51}$

50 Castro, "Aqui jaz um cemitério", p.30.

51 Rosa, "A relação das áreas de cemitérios públicos", pp.45-7. As sete irmandades mencionadas pela autora são: Irmandade do Divino Espírito Santo, Irmandade Senhor Jesus dos Passos, Irmandade Nossa Senhora do Rosário e São Benedito, Irmandade Nossa Senhora do Parto, Irmandade Nossa Senhora da Conceição, Irmandade do Santíssimo Sacramento e a Ordem Terceira de São Francisco de Assis. 
Teria a Irmandade do Rosário providenciado a exumação de irmãos e irmãs enterrados no cemitério público? Como procedeu? Pela documentação pesquisada, essas indagações ficam sem respostas. Sabemos, no entanto, pelo estudo realizado por Maristela dos Santos Simão, que o cemitério localizado no bairro Itacorubi abriga atualmente ex-membros da irmandade, com cruz da irmandade identificada com o letreiro I.B.N.S.R.S.B. (Irmandade Beneficente Nossa Senhora do Rosário e São Benedito, conforme passou a se denominar com a reforma do compromisso em 1905).

No ossuário, sob a cruz, é pertinente pensar que alguns dos ossos ali depositados remetam a pessoas sepultadas ainda dentro da capela, e que já passaram, antes dali, pelo espaço ao lado da Igreja e pelo Cemitério Municipal no Bairro Estreito. ${ }^{52}$

No caso das irmandades, havia um cuidado com os mortos e seus sepultamentos. Na Irmandade do Rosário, muitos foram os associados falecidos cujos enterramentos ocorreram por conta da associação e com todas as pompas possíveis, de acordo com os direitos do morto e os cofres da agremiação. A morte constituía um evento, pois, assim como os demais acontecimentos do ciclo da vida (nascimento, crescimento, intempéries, etc.), estabilizava esse ciclo natural, reestruturando a ordem. Tais acontecimentos eram vivenciados como práticas mágico-religiosas, espetáculos da vida para os quais não sabemos a explicação, mas sobre os quais criamos significados, inserimos expectativas e reatualizações. A morte significa desordem em relação ao quotidiano; por mais que seja esperada e preparada, indica uma ruptura. Assim, organizar o "espetáculo fúnebre" reconstituía a ordem perdida, "ajudando os vivos a reconstruir a vida sem ele [o morto]", significando positivamente o seu lugar no mundo dos mortos. Como um dos fenômenos sociais, a morte e os ritos a ela associados ligavam-se à tarefa de desvincular, desagregar o morto do domínio do universo dos vivos e introduzi-lo no dos mortos. ${ }^{53}$

Os ritos fúnebres em culturas de matriz africana, assim como os

Simão, Lá vem o dia a dia, lá vem a Virge Maria, p.102.

53 José Carlos Rodrigues, Tabu da morte, Rio de Janeiro: Achiamé, 1983 apud Rodrigues, Lugares dos mortos, p.173. 
demais momentos de passagem — nascimento, casamento, ritos de iniciação, etc. - , são fundantes, pois refazem tempos cíclicos, constituem fluxos contínuos, potencializando vivências comunitárias. A morte, nesse caso, não significa o abandono de um corpo inerte, inativo, mas reatualização de sua experiência de vida, no sentido de celebrar seus feitos e sua memória. Essa forma de lidar com a morte utiliza-se das experiências do morto para o funcionamento de suas comunidades, pois as práticas ligadas à morte potencializam a vida, são significativas para o estabelecimento da renovação, ressignificação e reatualização "de tudo" e de "todos". Os vivos reunidos em solidariedade ao morto, "recuperavam algo do equilíbrio perdido com a visita da morte, afirmando a continuidade da vida". ${ }^{54}$

Sendo um elo entre o mundo dos vivos e dos mortos, celebrar esse momento, essa passagem, significava vivenciar a morte como capacidade de renovação de equilíbrio que salvaguarda interações presente/passado das próprias tradições, usos e costumes. Implicava o sentido de uma energia que circulava sob o regime distinto das culturas ocidentais, isoladas e atomizadas nos sujeitos individuais. Esse modo de experienciar a morte, como parte da vida e necessária ao reestabelecimento do equilíbrio, é coletivo, constituído de valores e saberes a serem preservados, decorrendo daí a importância de celebrar a vida e a memória dos mortos, pois seus corpos não são considerados matéria inerte, um cadáver apenas, como supõe a ciência ocidental. O corpo não se extingue no momento da morte, pois sua função, a partir da passagem para o mundo dos mortos, seria atuar nesse mundo para estabelecer, ou manter, o equilíbrio.

O corpo de uma pessoa possui sentidos, demonstra formas culturais e compreensões de mundo, diferenciadas em cada cultura. É no corpo que se operam mudanças, que se recebe o poder de alguma coisa ou de alguém, de um morto. ${ }^{55}$ Nele estão impregnados símbolos, resíduos, energias e códigos que se põem em ligações múltiplas, dinâmicas. Quando o corpo sofre alterações, como em caso de doença, ou mesmo de morte, as memórias e experiências vivenciadas pelo corpo não se extinguem com o cadáver, em ditames da ciência ocidental.

\footnotetext{
54 Reis, A morte é uma festa, p.138.

55 José Gil, Metamorfoses do corpo, Lisboa: Relógio D’Água, 1997, p.26.
} 
Esses signos, codificações presentes no corpo precisam ser entendidos, reafirmados e desenrolados em práticas, permitindo que a passagem do mundo dos vivos ao mundo dos mortos seja adequada, e que a ordem natural de viver e morrer seja mantida. O corpo, codificado segundo traços de sua cultura, é uma linguagem que, afastada de reconhecimento e afeto (entendimento desses códigos), não se sustenta. ${ }^{56}$ Talvez, as lógicas de sentido de culturas africanas na diáspora, seus modos de reatualizar e ressignificar práticas, tenham possibilitado ao corpo do morto adentrar o mundo dos mortos, auxiliando na administração de energias do mundo dos vivos. Os ancestrais possuem papel significativo na consolidação dessa transição, ritual e comunitária, em que a morte não constitui experiência a ser vivenciada na solidão mas em conjunto.

Diante desse modo de ver o mundo, percebe-se uma disputa cultural com a Igreja Católica, que afirmava sua

supremacia no tocante a estes assuntos [de morte], sendo sua visão de salvação a ser seguida. Nesse modo de lidar com a morte, a Igreja não demonstrava preocupação com o corpo, voltando seu foco apenas para o cuidado da alma.

A morte estava dentro dos limites da religiosidade, circunscrita ao perímetro da fé. "Nesse sentido, pouco importava o que era feito do corpo, considerado mero invólucro da alma, da qual importava a salvação". ${ }^{57}$ Cumpre destacar que a própria forma de compreensão do corpo morto, a ser velado e sepultado pela Igreja dentro de seus preceitos, possui variações ao longo do tempo. Até as primeiras décadas do Império, o corpo morto integrava o universo do sagrado, pois corpo e alma estavam ligados. A própria preocupação com os ossuários nos túmulos apontava que, quando chegasse o momento da ressurreição, o corpo "seria recomposto em todo o seu esqueleto - o único a sobreviver à decomposição. [...] Ao corpo morto também era atribuída uma função ou um papel no processo que culminaria na ressurreição", ${ }^{58}$

56 Gil, Metamorfoses do corpo, p.42.

57 Pereira, À flor da terra, p.88.

58 Cláudia Rodrigues e Maria da Conceição Vilela Franco, "O corpo morto e o corpo do morto entre a Colônia e o Império", in Mary Del Priore e Marica Amantino (orgs.), História do corpo no Brasil (São Paulo, Editora da Unesp, 2011), pp.157-83. 
O entrelaçamento entre corpo e alma era muito forte, envolvendo cuidados com a saúde e cuidados com a morte, visto que um dos receios de ter o corpo insepulto era de que a alma não encontraria a salvação. "A preocupação com o abrigo do corpo morto nos sagrados templos católicos levou a que, em seu interior e seu redor, os vivos convivessem cotidianamente com as várias sepulturas", ${ }^{59}$ prática essa alterada na segunda metade do século XIX.

A visão cartesiana do mundo implicou alterações na forma de lidar com a relação entre corpo e alma. O corpo virou cadáver, deixando de possuir significados entrelaçados à alma. Essa perspectiva também foi incorporada pelas ciências médicas do século XIX, tanto que os corpos mortos passaram a ser considerados danosos aos corpos dos vivos, pois os miasmas emanados pelos primeiros significariam doenças e epidemias para os segundos. Não à toa, cemitérios passaram a ser construídos ou foram transferidos para regiões periféricas das cidades. ${ }^{60}$ No entanto, a medicalização não implicou a concretização imediata de alterações nas práticas das pessoas.

Para além dessa visão mais preocupada com a alma e sua salvação, as culturas de matriz africana produziam seus corpos com códigos culturais, marcas de vida e experiência. $\mathrm{O}$ corpo precisava ser cultuado, pois estava embrenhado de vivências, saberes e práticas a serem transmitidas, repensadas e reatualizadas, não necessariamente ligadas à ideia de alma e salvação atribuídas pela Igreja Católica.

Assim como as festas compunham momento de reatualização, de estabelecimento da ordem e sentidos para continuar as demais atividades do ano, também a morte, sua celebração coletiva, seus sentidos, encontros e sociabilidades, estabilizava os mundos. Vida e morte, choro e riso, ${ }^{61}$ sagrado e profano e outras dicotomias impostas pela visão de mundo ocidental não constituíam oposições nas culturas de matrizes africanas.

59 Rodrigues e Franco, "O corpo morto e o corpo do morto", p.170.

${ }^{60}$ Rodrigues e Franco, "O corpo morto e o corpo do morto", p.181.

${ }^{61}$ É interessante trazer a descrição do viajante Louis Choris, destacando uma passagem em que comentava "negros dançando e chorando ao mesmo tempo", pois, em culturas de origem africana, riso e choro, cantar e chorar ao mesmo tempo não constituíam oposição. Consultar: Martim Afonso Palma de Haro (org.), Ilha de Santa Catarina: relatos de viajantes estrangeiros nos séculos XVIII e XIX, Florianópolis: Editora da UFSC/ Lunardi, 1996. 


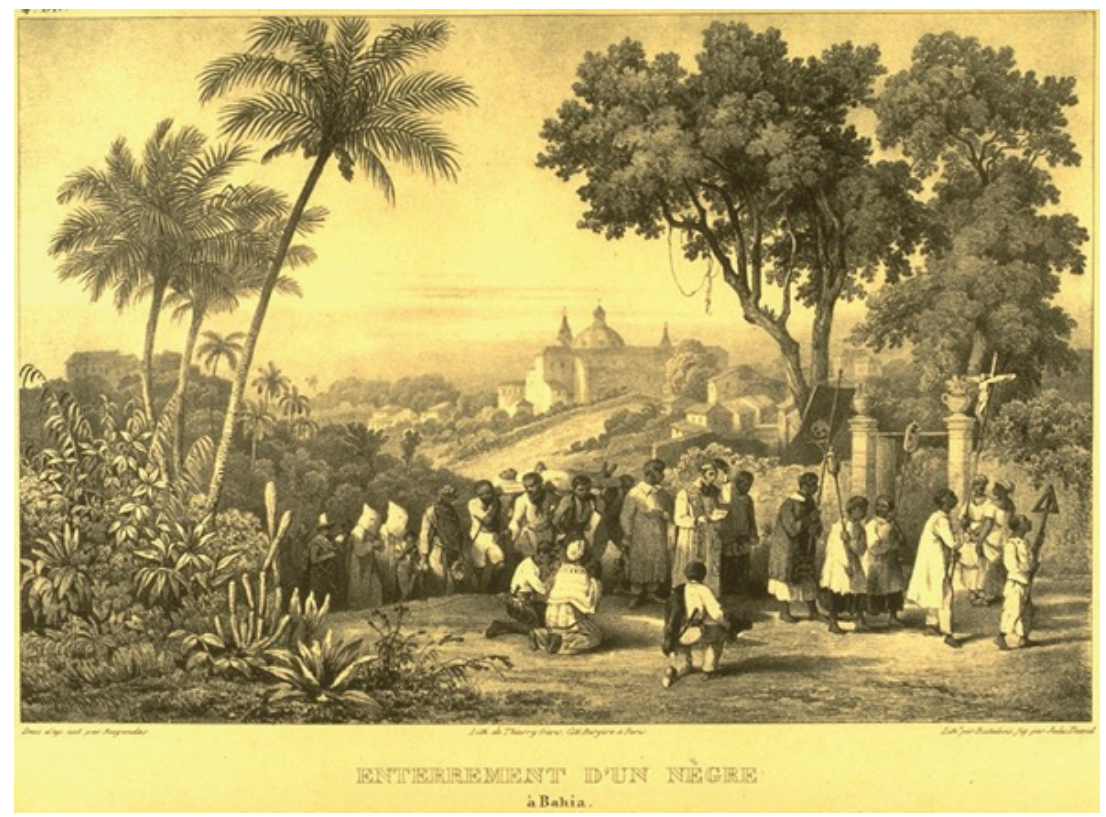

Figura 3 - Johann Moritz Rugendas. Enterro de um negro na Bahia, c. 1830.

Fonte: $<$ http://www.google.com.br/imgres?hl=pt-BR\&client=firefox-a\&hs $=$ WOb\&sa $=X \& t b o=d \& r l s=o r g$. mozilla:pt-BR:official\&biw $=1358 \&$ bih $=614 \& t b m=i s c h \& t b n i d=j O 8 K N d-i K h V y b M: \& i m g r e f u r-$ I=http://people.ufpr.br/ Igeraldo/upoimagens4.html\&docid=eo0EsfBf2sJVoM\&imgurl=http:// people.ufpr.br/ /geraldo/funeralbahia.jpg $\& w=1143 \& \mathrm{~h}=900 \&$ ei $=$ iFP4UKDDFvKK0QHqr4DgDA$\& z o o m=1 \&$ iact $=\mathrm{hc} \& \mathrm{vpx}=447 \& \mathrm{vpy}=10 \& d u r=1595 \& \mathrm{hovh}=199 \& \mathrm{hovw}=253 \& \mathrm{tx}=95 \& \mathrm{ty}=149 \& \mathrm{-}$ sig $=110655742944068515042 \&$ page $=1 \&$ tbnh $=138 \&$ tbn $w=175 \&$ start $=0 \& n d s p=24 \&$ ved $=-$ $1 \mathrm{t}: 429, \mathrm{r}: 3, \mathrm{~s}: 0, \mathrm{i}: 91>$.

Essas dicotomias foram incapazes de explicar os modos de vida dessas populações, mas isso não impediu que formas eurocêntricas de ver o mundo categorizassem, nomeassem negativamente e usurpassem saberes e práticas julgadas por olhares racializantes. Cremos que esses valores estiveram em constante conflito no século XIX e nas primeiras décadas do $\mathrm{XX}$, pois o modo de vida das populações de origem africana em Desterro/Florianópolis não condizia com os "novos ares" republicanos nem com as práticas exigidas pelo catolicismo.

A Figura 3, uma obra de Rugendas, em visita ao Brasil no século XIX, possibilita percepções sobre como era conduzido o funeral de uma irmandade religiosa organizada por africanos e seus descendentes. 
Percebe-se que todos estão descalços, sinal alusivo à condição de cativos dos acompanhantes do cortejo, exceto o padre e alguns membros mais ao final da procissão. À frente, segue um jovem carregando a cruz, acompanhado de dois meninos conduzindo as tochas e um adulto, portando um estandarte indicativo de um cortejo fúnebre, tendo em vista a caveira retratada na flâmula. O padre parece ocupado em leitura da Bíblia, organizando as orações ao morto, carregado num caixão aberto, logo atrás, por um grupo de homens. Ao lado do padre, sacristãos, um deles utilizando um turíbulo e dispersando incenso. O corpo aparenta estar coberto por uma espécie de mortalha cuja cor, tipo de tecido, ou se possui algum indício de relação a um santo de devoção não é possível identificar. Em seguida ao caixão, uma mulher e uma criança. Seriam a mulher e o filho do morto, que parecem secar as lágrimas levando a mão ao rosto? Não sabemos exatamente, mas são possibilidades diante de um momento quotidiano e repleto de significados na vida e na morte. A pintura de Rugendas evidencia, ainda, um cortejo organizado em alas distintas, compondo a apresentação do morto ao seu destino, o mundo dos mortos.

Segundo o costume, vários componentes formavam as alas que davam ao cortejo um andamento, ritmado pelos cânticos da condução do corpo do morto sobre o caixão fúnebre. Fazia-se fundamental o preparo organizado pelos vivos para a passagem do morto, porque, em se tratando de populações africanas e seus descendentes, preparava-se o encontro com os ancestrais, diferentemente da ideia cristã de "salvar a alma" do morto. Uma das formas de concretizar essa passagem era a utilização de mortalhas adequadas, roupas que pudessem facilitar e embelezar essa transição ${ }^{62}$ que depois seriam guardadas por seus familiares.

De acordo com Reis, os tipos de mortalha compunham os desejos finais do morto e o acompanhariam na hora da passagem. O tipo de mortalha ou roupa que cobria o defunto variava bastante, não existindo um padrão, havendo "mortalhas brancas, pretas, coloridas, vermelhas. Havia mortalhas que imitavam roupas de santos, como a franciscana, as de várias invocações de Nossa Senhora, as de são João, são Miguel, são

${ }^{62}$ Rodrigues, Lugares dos mortos, p.196. 
Domingos, santo Agostinho, santa Rita, santa Ângela". ${ }^{63}$ Ao analisar as vestes mortuárias de irmandades de origem africana na Bahia, percebeu que, em muitos casos, a preferência dos mortos era pela mortalha franciscana, uma herança ibérica, ou pela mortalha branca, cor funerária utilizada no candomblé. ${ }^{64}$ "Vestir o cadáver com a roupa certa podia significar, [...] salvação. [...] A mortalha falava pelo morto, protegendo-o na viagem para o além, e falava do morto como fonte de poder mágico, mas também enquanto sujeito social". ${ }^{65}$ Segundo interpretação do autor, as irmandades forneciam as mortalhas aos irmãos pobres que, em geral, eram brancas, visto ser a mais comum entre os pobres.

Aparentemente, as irmandades não tinham orientação definida quanto ao tipo de mortalha usado por seus membros. Nenhum compromisso, por exemplo, obrigava ou mesmo recomendava ao irmão esta ou aquela mortalha. As irmandades negras forneciam mortalhas aos irmãos pobres e a do Rosário das Portas do Carmo chegou a mencionar no compromisso de 1820 que 'lhe dará pelo amor de Deus uma mortalha branca', a típica roupa fúnebre de pobre. ${ }^{66}$

Enfim, conforme Mariza de Carvalho Soares, dada a preocupação com a morte, muitos africanos e afrodescendentes, mesmo não possuindo bens materiais, faziam "testamento para deixar ali registradas as condições de seu sepultamento". De acordo com a autora, a preta Tereza de Jesus, forra mina, "casada com um preto forro, é amortalhada no hábito de Santa Rita e sepultada em Santa Efigênia", ${ }^{67}$ irmandade de pretos do Rio de Janeiro. No entendimento de Reis, os africanos tinham uma preocupação muito grande com os funerais para os seus mortos, experiência que "adaptou-se à tradição luso-barroca de pompa fúnebre". Assim, as irmandades acompanhavam e enterravam os seus mortos, rezavam por suas almas, num projeto para o "além vida". ${ }^{68}$ Essa preocupação com a morte era algo peculiar às irmandades, pois não apenas os ritos de

\footnotetext{
${ }_{63}$ Reis, A morte é uma festa, p.119.

64 Reis, A morte é uma festa, pp.117-8.

${ }_{65}$ Reis, A morte é uma festa, p. 124.

${ }^{66}$ Reis, A morte é uma festa, p.127.

67 Soares, "Escravidão africana e religiosidade católica", p.113.

68 Reis, A morte é uma festa, p.16.
} 
passagem, como os funerais, eram importantes, mas, "especialmente, as orações pós-morte pelas almas, que eram consideradas fundamentais para que os irmãos alcançassem a salvação". ${ }^{69}$

Florinda Emericiana de Sousa, liberta, associada à Irmandade de Nossa Senhora do Rosário e São Benedito de Desterro/Florianópolis desde 1860, faleceu em 9 de dezembro de 1911, ano em que os sepultamentos aconteciam no antigo cemitério, e seu corpo seguiu, provavelmente, em cortejo até a sepultura em espaço destinado à irmandade. Ao que tudo indica, Florinda teve um funeral digno de sua participação e atuação na irmandade: procissão, enterro no cemitério da associação, sinos repicando ao vento e informando a todos que a irmã do Rosário falecera. A bandeira com a insígnia da irmandade seguia à frente, como distintivo, e seus membros vestiam-se com as tradicionais opas brancas. As tochas seguiam a iluminar o caminho do morto, os associados acompanhavam o trajeto cantando, às vezes seguindo a banda musical contratada para o cortejo, dependendo dos recursos disponíveis da irmandade. Florinda Emericiana de Sousa talvez vestisse a comum mortalha branca, ou, quem sabe, tivesse optado por uma mortalha associada aos seus santos de devoção. A irmandade costumava adquirir muitos rosários, em parte para distribuição nas festas, durante as procissões e celebrações, e também para uso em momentos fúnebres. Reis percebe algo interessante no que tange ao uso do rosário amarrado às mãos do morto e os significados de suas cores: "rosários pretos para homens e mulheres casados, azuis para as virgens, brancos para as crianças, roxos para as viúvas. Entre as mãos, uma vela acesa para iluminar os caminhos". ${ }^{70}$

Sobre o cortejo fúnebre organizado por irmandades de origem africana, Júlio César Medeiros da Silva Pereira, alude a algumas práticas culturais e elementos utilizados e/ou incorporados pelas populações de origem africana em seus ritos fúnebres católicos na cidade do Rio de Janeiro:

O cortejo composto do padre, dos irmãos de irmandade, curiosos e pessoas que acompanhavam, ia até a residência do morto. Dali, o morto

69 Alves, "Irmãos de cor e de fé", p.86.

70 Reis, A morte é uma festa, p.130. 
seria transportado para o local do sepultamento. As pessoas se aglomeravam para observar a cena, um outro grupo composto pelos irmãos da irmandade, conhecidos como transeuntes, acompanhava o corpo inerte transportado numa esteira, sob o ritmo de uma fanfarra de negros. $\mathrm{O}$ percurso deveria findar na igreja em que fosse acontecer o sepultamento. ${ }^{71}$

Esses dados são valiosos por acompanhar o trajeto do corpo até seu destino. O caso narrado enfoca um sepultamento que, normalmente, ocorria até meados do século XIX, visto o destino final ser a igreja ou capela ${ }^{72}$ onde seria inumado o morto, prática comum até meados do século XIX, quando as Posturas Municipais criaram regras "mais higienizadas" para os enterramentos e cemitérios. ${ }^{73}$

Entretanto, o recorte temporal não impede que façamos aproximações com práticas posteriores a esse período. O cortejo saía da casa do falecido, o conjunto de pessoas — associados à irmandade, familiares, curiosos, conhecidos - acompanhava a comitiva carregando o morto numa esteira ou esquife — comum às irmandades —, caminhando ao ritmo entoado por uma fanfarra, ou banda, de músicos africanos e afrodescendentes.

Marcelina Maria da Conceição, crioula liberta, morava na residên-

${ }_{71}$ Pereira, À flor da terra, pp.57-8.

72 No Brasil, principalmente até a segunda metade do século XIX, o sepultamento no interior das igrejas era costume. Ser enterrado próximo ao altar significava ocupar um cargo importante na vida religiosa daquela capela ou irmandade. Esse era o objetivo de muitos devotos quando de seu falecimento. De acordo com Elisiana Castro, "os enterramentos cercavam os altares, as paredes, o chão de capelas e matrizes e, quanto mais próximo aos santos e ao altar, mais desejado era o local da sepultura. A crença que sustentava tal prática era a de poder ser salvo, no dia do Juízo Final, por estar 'repousando' mais próximo do altar sagrado. Estando o cemitério dentro das igrejas, o cotidiano da morte prescrevia uma proximidade entre mortos e vivos, que também se dava por meio de ritos, como a realização de cortejos e de velórios em casa, ritos que estão caindo em desuso, sobretudo nos centros urbanos brasileiros". Consultar: Castro, Um chão para cair morto, p.4.

73 No entanto, como bem ressaltou João José Reis, a população reagiu a essas medidas, pois o catolicismo vivido compreendia o espaço da igreja como sagrado e, desse modo, ser enterrado nesse espaço conferia certo status e aumentava as possibilidades de salvação da alma. A Cemiterada, conforme destaca o autor, demonstra o significado dessa alteração na vida das pessoas comuns, habituadas com o enterro nas igrejas e os sentidos dessa prática: "Pois o enterro nas igrejas era visto como uma das estratégias de salvação da alma. [...] Com a chegada da morte se preparava o morto para o funeral. [...] Os funerais eram pomposos, e para isso contribuía o número de participantes no cortejo, de padres, confrades, pobres, músicos, parentes, amigos e estranhos". Ver: Reis, A morte é uma festa, em especial o capítulo 1. 
cia do senhor Abel Ignácio da Silveira, quando, em 1866, aos 37 anos, matriculou-se na irmandade. A mesma Marcelina aparece registrada novamente em 1905, na condição de livre, quando entra para a beneficência, pois, ao que tudo indica, não possuía mais condições de sobreviver por sua própria conta, talvez em virtude da idade ou de alguma doença que a impossibilitava de trabalhar. Marcelina estava, então, com 70 anos, e não há registros de onde residia. Talvez não morasse mais na residência de Abel Ignácio da Silveira. Ela faleceu em 31 de dezembro de 1908, aos $73 \operatorname{anos}^{74}$ e teve seu funeral organizado pela Irmandade de Nossa Senhora do Rosário e São Benedito, sendo sepultada no espaço da associação dentro do Cemitério Municipal. "Para o transporte do féretro havia toda uma infra-estrutura montada e especializada, que permitia o deslocamento do cortejo fúnebre". ${ }^{75}$ As ruas chamavam a atenção pelo repique dos sinos, as vozes a cantar, a banda de músicos a acompanhar a procissão com o corpo do morto carregado no caixão pelos irmãos da agremiação. O caminho, até o cemitério, passava pela Rua do Príncipe (atual Conselheiro Mafra), supondo-se sua saída da capela da irmandade, conforme imagem disponível no mapa (Figura 4). A partir de 1925, quando os mortos passaram a ser sepultados no cemitério do Itacorubi, o trajeto ficou mais longo, fora do perímetro destacado no mapa, pois o novo cemitério ficava no sentido oposto ao Cemitério do Estreito.

O funeral, antes de direcionar-se ao cemitério, realizava práticas litúrgicas na casa do falecido e na própria capela da associação à qual pertencia. A encomendação da alma era feita pelo pároco, na presença de conhecidos, familiares e irmãos da associação, cujo rito envolvia música. Mas os procedimentos não findavam no cemitério. Após o cortejo e o sepultamento, cuidava-se dos resquícios deixados pela morte e, sempre que possível, rezavase pelos falecidos, mandando celebrar uma missa por sua alma.

Tendo saído o enterro, procurava-se apagar os rastros da morte em casa. As roupas do defunto, especialmente suas roupas de cama e o colchão (no que sono e morte aparecem associados), eram destruídas ou jogadas

\footnotetext{
74 Tabela de Registro de Irmãos 1816-1937. Acervo da Irmandade de Nossa Senhora do Rosário e São Benedito dos Homens Pretos. Transcrição realizada por Maristela dos Santos Simão e Michelle Maria Stakonski.

75 Rosa, "A relação das áreas de cemitérios públicos”, p.40.
} 


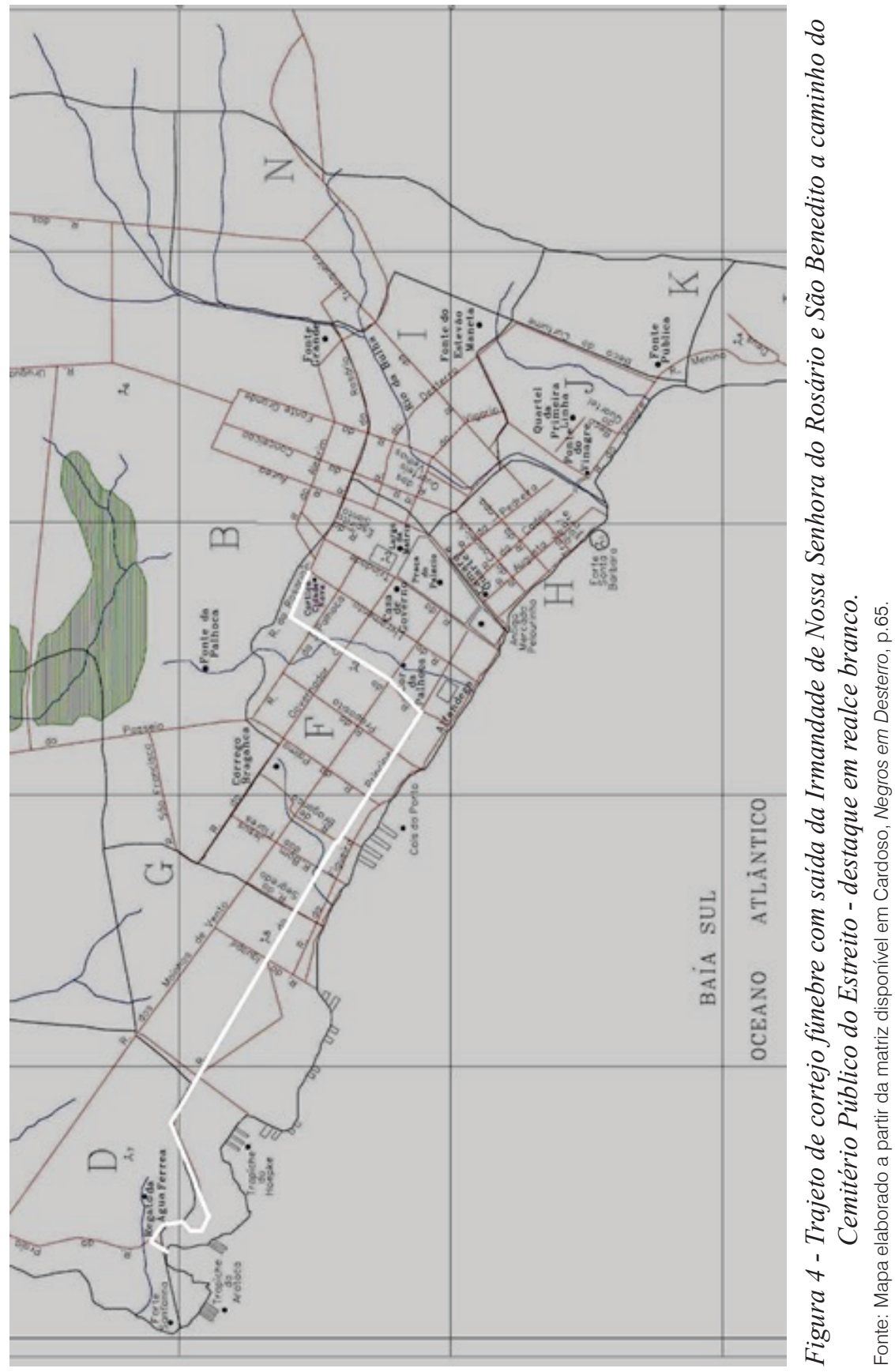


fora. Varria-se a casa cuidadosamente, lançando a poeira pela porta da frente, que permanecia semicerrada como sinal de luto e para facilitar a saída da alma do morto, caso ainda rondasse por ali. ${ }^{76}$

Em importante trabalho sobre as irmandades de pretos em Pernambuco e no Rio de Janeiro, Antonia Aparecida Quintão registra, de modo enriquecedor, os procedimentos fúnebres destinados ao morto:

Em falecendo algum nosso irmão ou irmã [...] indo na nossa tumba se tocará o sino e todos os irmãos que morarem na povoação e seus arredores, sendo avisados pelo Procurador se ajuntarão na nossa igreja, para que saiam em ordem acompanhando a cruz e guião com suas opas brancas e tochas ou velas nas mãos e pela rua irão todos com muita compostura e modéstia até a parte onde estiver o corpo do irmão ou irmã defunta e daí irão com a mesma ordem até a igreja donde se for sepultar. ${ }^{77}$

Era função do Procurador ou, em algumas irmandades, do Irmão Andador avisar a todos o falecimento de um membro e chamá-los para o cortejo. O Compromisso da Irmandade de Nossa Senhora do Rosário e São Benedito de Florianópolis, de 1905, especificava, como função do Procurador de Caridade: em "caso de falecimento de algum irmão, logo que receba aviso, comunicar ao irmão Juiz para este dar ordem de fornecer o funeral por conta da Irmandade". ${ }^{78}$

A cruz e o guião (estandarte da associação que vai à frente às procissões e demais atos importantes da agremiação), símbolos da associação, integravam a solenidade, estando os Irmãos da Mesa Administrativa trajados com as opas brancas destacando a distinção da irmandade, levando tochas ou velas nas mãos durante o trajeto do préstito. Todo esse aparato em celebração à morte de um membro simbolizava a concretização de uma "boa morte".

A boa morte significava que o fim não chegaria de surpresa para o indivíduo. Esta seria uma forma de "morte bonita", em que morrer

76 Reis, A morte é uma festa, p.132.

77 Compromisso da Irmandade de Nossa Senhora do Rosário dos Homens Pretos da Freguesia de Santo Antonio do Cabo, Pernambuco, 1765 apud Quintão, Lá vem o meu parente, p.159.

78 Compromisso da Irmandade de Nossa Senhora do Rosário e São Benedito de 1905, capítulo VIII - Atribuições dos irmãos Procuradores de Caridade. Acervo da Irmandade de Nossa Senhora do Rosário e São Benedito. Transcrição da autora. 
era um esforço coletivo. O fim da vida não poderia ser uma experiência solitária, ${ }^{79}$ a preparação para a morte envolvia, em vida, a coletividade de irmãos e irmãs, por ser uma situação fundamental da vida, algo significativo nas vivências comunitárias das populações de origem africana no seu universo cultural.

Saliente-se o papel fundamental da morte no equilíbrio dessas culturas, regidas por tempos cíclicos - em que vida e morte fazem parte da vida - porque seus saberes e valores, tradições e códigos culturais são preservados, transmitidos entre gerações. Até na morte, em sociedades mantidas em perspectivas de tempo linear, forjados em sociedades de progresso e desenvolvimento (ocidentalizadas e ocidentalizantes), visões de mundo europeias e africanas revelam seus desencantos. No Ocidente, a morte é enxergada e cultivada como expressão de finitude, superada em vida por si mesma, sendo os ritos fúnebres desfigurados enquanto conexão entre vida e morte.

A Irmandade do Rosário dispendeu muitos recursos para atender às demandas mortuárias e ritos fúnebres de seus associados. Estar com os anuais em dia era um dos requisitos para ser enterrado como membro da irmandade e com as pompas que ela possibilitava. No entanto, mesmo com esses recursos prévios pagos pelo filiado, os gastos eram grandes: pagamento ao padre para a missa, pagamento ao coveiro para a abertura da sepultura, compra de ceras, velas, flores e pagamento ao capelão.

Em abril de 1900, a Irmandade dispendeu $18 \$ 000$ (dezoito mil réis) para pagamento do coveiro do cemitério pela abertura de sepulturas no "Cemitério desta Irmandade, sendo 4 maiores e uma menor". ${ }^{80}$ Nesse caso, chama a atenção a indicação do cemitério da irmandade. Tendo em vista que, nesse período, já não se realizavam os sepultamentos dentro das capelas ou ao seu redor, é muito provável que a irmandade seguisse a prática de enterrar seus mortos no Cemitério Municipal.

Ter acompanhamento funeral, um lugar certo para sepultamento, sinos tocando, orações, missas e rezas pela alma durante a passagem ao além-vida era privilégio dos associados. Em vários capítulos dos

\footnotetext{
79 Reis, A morte é uma festa, p.100.

80 Livro Caixa 14 (1899-1906), p.14. Acervo da Irmandade de Nossa Senhora do Rosário e São Benedito.
} 
Compromissos das Irmandades ${ }^{81}$ Quintão constatou a importância do sino para os confrades:

Cap. $13^{\circ}$ Quando morrer qualquer irmão ex-Juiz, o Juiz mandará fazer por ele os sinais, principiando pelo sino grande, e depois de empinar quatro vezes entrarão os outros. Pelo Escrivão, Juízes brancos, Juízas, Pessoas Reais, Bispo e General da capitania, também deve se principiar pelo grande, porém só com duas vezes de empinado, e não mais por pessoa alguma terá princípio pelo referido sino grande. $[\ldots]$

Cap. $28^{\circ}$ (O rei) também será obrigado a fazer governador em cada Nação, e os que vierem tomar posse nesta Igreja, e ao dito Rei no dia de sua posse o receberá a Irmandade com repiques de sinos". ${ }^{82}$

Os sinos eram empregados em diferentes momentos da existência associativa, sendo importante realçar a celebração da vida, da festa e da morte. "E, pelo toque do sino em finados, ao longe, já se sabia que havia falecido um irmão do Rosário, do Carmo ou do Santíssimo". ${ }^{83}$ Fazer soar os repiques dos sinos funcionava como um aviso em locais comunitários, pequenas vilas. Ao longe, ouvia-se o rufar do tambor e as vozes que contagiavam a curiosidade de alguns viajantes, assim como os sinos cujos dobres emitiam sinais, identificavam a morte e quem morreu.

${ }^{81}$ Compromisso da Irmandade de Nossa Senhora do Rosário das Portas do Carmo - Salvador/BA (1820): "Quando qualquer irmão falecer, e for enterrado no ato da Irmandade se convocará esta no maior número de que puder ser, e todos com suas capas, e velas em duas alas com o Esquife, guião, e manga, irão buscar para a capela onde será enterrado, e não faltará sair com o Esquife o Capelão, ou outro sacerdote a seu rogo, e os Juízes com mais irmãos que poderem, e se acharem no dito ato, cobrirão a Irmandade levando capas e tochas distintas". Reginaldo, Os rosários dos angolas, p.200. Compromisso da Irmandade de Nossa Senhora do Rosário dos Pretos de Ouro Preto - MG (1750): "Assim que falecer algum Irmão ou Irmã, branco ou preto forro ou cativo, se fará logo saber ao Procurador, ou Sacristão da Irmandade, o qual avisará logo esta, não só fazendo com os sinos os sinais costumados para o enterro, e juntos que sejam, sairão todos com suas opas brancas, levando o Sacristão, ou outro qualquer irmão adiante a cruz, e quatro Irmãos a tumba da Irmandade e atrás de todos, irá o Juiz de Nossa Senhora, ou outro qualquer dos mais santos, que presente se achar, com sua vara, e levará à sua mão direita o Reverendo pároco Capelão, e chegados à porta do Irmão defunto, entrará o Reverendo Pároco a encomendá-lo, o que feito mandará o juiz meter na tumba o corpo do defunto, e postos os Irmãos em duas fileiras com a cruz adiante, levantada, levarão o corpo até a sepultura, que lhe estiver destinada em nossa igreja ou outra qualquer onde for sepultado nesta vila, e o Procurador irá regendo a Irmandade para que vá com toda modéstia, e compostura, que se requer em aqueles atos, rezando pela alma do dito defunto". Reginaldo, Os rosários dos angolas, p.201.

82 Compromisso da Irmandade de Nossa Senhora do Rosário de Recife, 1758 apud Quintão, Lá vem o meu parente, p.195.

83 Salles, Associações religiosas no ciclo do ouro, p.103. 
Anunciava-se, pelo toque do sino, a partida, e a necessidade de organização comum para os encaminhamentos do morto ao mundo além-vida. $\mathrm{O}$ sino transmitia a notícia, ao passo que as sinetas chamavam o povo para o cortejo ${ }^{84}$ pois eram utilizadas durante a procissão fúnebre, anunciadoras da passagem do préstito por ruas e praças, até a chegada ao cemitério.

Relacionando experiências afrodiaspóricas e africanas, Quintão retrata os sinos como "emblemas de chefia política" utilizados por pessoas de elevado estatuto social.

A relação entre os sinos e a chefia pode datar de antes do primeiro milênio. Sinos redondos sem badalo encontravam-se em número preponderante entre os bronzes produzidos ao sul da Nigéria, por volta do século XV. Sinos quadrados figuravam nas insígnias usadas pelos governantes do Benim no século XVI e nos altares erigidos aos antepassados. Na África Central, sinos duplos como insígnias de reis e da nobreza eram mais comuns e consistiam de 'dois sinos cônicos de ferro de tamanho desigual'. Os sinos eram tocados pelos servidores para anunciar a presença sagrada de um soberano e julga-se que a sua função simbólica era de convocar os antepassados, estabelecendo 'campos de poder' à volta do rei. ${ }^{85}$

Ao que tudo indica, os sinos caracterizavam um ponto de tensão entre a Irmandade do Rosário e as autoridades eclesiásticas, principalmente aquelas reunidas nos sínodos diocesanos. Em 1910, quando se realizou o Primeiro Sínodo, vários pontos foram discutidos pela Igreja Católica, ações que deviam ser implementados para a concretização de seus propósitos. Muitas práticas realizadas constantemente pelos leigos faziam parte das associações religiosas em geral, as irmandades em especial, sendo, no entanto, desaprovadas pela Igreja.

${ }_{84}$ Parece-nos importante destacar essa passagem discutida por Mara Regina do Nascimento. A autora possui uma visão restrita das práticas religiosas, festivas e mortuárias realizadas por africanos e seus descendentes na Irmandade de Nossa Senhora do Rosário, São Domingos e São Benedito, incluindo as manifestações culturais e devocionais dessas populações no mesmo universo das irmandades organizadas por brancos. Para a autora, a irmandade organizada por africanos e afrodescendentes era igual a irmandades construídas por brancos, o que, em nosso entendimento, é equivocado, visto que tal ponto de vista exclui universos culturais africanos e suas práticas na diáspora, apesar de estarmos discutindo uma irmandade católica. Ver: Nascimento, "Irmandades leigas em Porto Alegre".

85 Jill R. Dias, África, nas vésperas do mundo moderno, Lisboa: Universidade Nova de Lisboa, Comemorações dos descobrimentos portugueses, pp.220-1 apud Quintão, Lá vem o meu parente, p.156. 
Essas tensões podem ser percebidas pelo uso dos sinos e, de certo modo, as pressões eclesiásticas em relação às atitudes e formas de viver o catolicismo experimentadas pelas populações de origem africana. Segundo norma do Sínodo Diocesano de 1910, "não permitam os dobres a finados como sinais de festa, e só nas cerimônias fúnebres ou na quaresma". ${ }^{86}$ A normativa proposta pela Igreja voltava suas atenções ao modo como estava sendo vivenciado e praticado o uso do sino em situações de morte. Assim, na visão do catolicismo - romanizado, mais rígido e menos condizente com práticas exteriores de fé —, os dobres de sinos, expelidos das capelas, quando da morte de algum associado da irmandade, não deveriam manifestar uma possível celebração festiva para o morto. Mas, como destaca Reis, "em nome da boa morte, os fiéis rompiam com as normas da Igreja, que proibia os funerais noturnos, os insistentes dobres de sinos e música na rua". 87

As pessoas não compunham apenas as celebrações festivas de reis e rainhas, Nossa Senhora do Rosário ou São Benedito, mas se faziam presentes nos festejos fúnebres, exteriorizando no cortejo suas devoções e concepções de morte. A morte portava um conteúdo público, a ser exteriorizado, demonstrado, vivido e compartilhado, muito além de sua dimensão privada, ${ }^{88}$ particular. A procissão, seguindo o caixão carregado pelos membros da irmandade, atraía pessoas, instaurava uma situação adversa ao dia a dia, tal qual a festa, mobilizando sentimentos e manifestações coletivas.

As sinetas chamavam os "admiradores" nas janelas, conhecidos, amigos, irmãos e irmãs para seguirem acompanhando o préstito. Esse era o espetáculo, a ostentação, a vivência e, não necessariamente, a inumação, o ato de enterrar o cadáver. Isso, no entanto, não exclui a importância de onde sepultar o corpo, pois o local de enterro também indicava uma condição. Ser enterrado em cemitérios, por exemplo, enquanto a prática era a realização dos sepultamentos nas igrejas e capelas, significava um descaso para com o morto, muitas vezes sendo o destino de indigentes e cativos.

Segundo Pereira, muitos são os códigos culturais presentes nos rituais mortuários nas mais variadas culturas, sendo o local de sepul-

\footnotetext{
${ }^{86}$ I Sínodo Diocesano de Florianópolis, 1910, p.100.

87 Reis, A morte é uma festa, p.139.

${ }_{88}$ Rodrigues, Lugares dos mortos, p.218.
} 
tamento carregado de implicações simbólicas. ${ }^{89}$ No caso das análises realizadas sobre os sepultamentos no Cemitério dos Pretos Novos no Rio de Janeiro, local de enterro de africanos recém-chegados oriundos das rotas do tráfico, o autor traz indícios de práticas expressas na própria forma e posição como os corpos eram inumados.

Por exemplo, a simples averiguação da posição dos caixões pôde revelar a preferência escrava em serem inumados com a cabeça na direção do norte. Sabemos que na África, muitos africanos foram sepultados em posições diferenciadas dos demais, que indicavam o momento particular da morte ou a posição social do morto. Desta forma, mortos por relâmpagos, suicidas, abortos e mortos em batalha possuíam tratamento mortuário diferenciado. ${ }^{90}$

Destacamos que tanto africanos como portugueses destinavam atenção especial aos seus mortos, e isso resultou em formas de lidar com a morte e práticas no Brasil. Para Reis, algumas preocupações assemelhavam-se, como a arte de banhá-los, cortar o cabelo, a barba e as unhas, vesti-los com roupas adequadas à ocasião ou com as mortalhas, conforme já mencionamos. Constituía objetivo dessas cerimônia tornar a passagem para o além mais segura, alegre e certificando-se de que a alma do morto completasse a transição, impedindo que ficasse entre os vivos a atormentá-los. ${ }^{91}$ Lidamos com aspectos, formas, artes e códigos de culturas diferentes,

próprias, revestidas de sentidos díspares, mas que foram amplamente reapropriadas e reelaboradas por ambas as tradições. Não se trata, pois, de simples aculturação nem assimilação de culturas, mas sim de reelaboração de significados. ${ }^{92}$

Algo que chama atenção a partir das reflexões de Reis refere-se ao modo como rituais mortuários africanos estabeleciam comunicação com o mundo dos mortos, diferentemente das propostas da Igreja Católica, cujo discurso pautava-se na salvação das almas. A constituição

\footnotetext{
89 Pereira, À flor da terra, p.97.

90 Pereira, À flor da terra, p.136.

91 Reis, A morte é uma festa, p.90.

92 Pereira, À flor da terra, p.174.
} 
de um catolicismo diferenciado, múltiplo, permitiu que, para além dos rituais católicos "oficiais", outras práticas culturais, simbólicas, fossem efetuadas pelas populações de origem africana na diáspora. "Os mortos ganharam mais importância no catolicismo popular, ainda impregnado de fortes componentes mágicos e pagãos. Nessa tradição figuravam como personagens poderosas, capazes de atormentar ou de ajudar os vivos". ${ }^{93}$

As celebrações constantes, demonstrando preocupação com os mortos, marcaram as atividades da irmandade. Seu compromisso possuía um capítulo destinado aos sufrágios de irmãos e irmãs.

\section{CAPÍTULO XVII - DOS SUFRÁGIOS DOS IRMÃOS}

Art. 29. Falecendo qualquer irmão que esteja quites com a Irmandade, o irmão Procurador dará as providências necessárias, para o que receberá ordens do juiz.

$\S 1$. A Irmandade deve acompanhar os corpos dos seus irmãos falecidos, não só aos jazigos da Irmandade como a outros particulares.

$\S 2$. Qualquer pessoa que desejar ser sepultada nos jazigos desta Irmandade dará uma joia de cinquenta mil réis, e terá direito ao que diz o $§ 7$ do art. 28.

$\S 3$. Todos os filhos legítimos de irmãos até a idade de oito anos, terão direito a ser sepultados nos jazigos da Irmandade.

$\S 4$. No caso de falecimento de qualquer pessoa que tiver o título de benfeitor da Irmandade ou que deixar legado a esta, o irmão juiz mandará fazer dobres de sino e rezar uma missa por sua alma. ${ }^{94}$

A missa pelas almas era prática corrente, no entanto, benfeitores tinham direito a uma missa "sem custos", ou seja, um benefício dado pela irmandade em gratidão às benesses oportunizadas pela benfeitoria do morto.

No que tange aos cargos mais importantes da Mesa Administrativa, Irmãs Juízas e Associados beneméritos, os cortejos fúnebres deveriam ser organizados de forma solene. As hierarquias existentes na confraria também implicavam pomposidade e reconhecimento na hora da morte:

93 Reis, A morte é uma festa, p.90.

94 Compromisso da Irmandade de Nossa Senhora do Rosário e São Benedito de 1905, capítulo XVII - Dos sufrágios dos Irmãos. Acervo da Irmandade de Nossa Senhora do Rosário e São Benedito. Transcrição da autora. 


\section{CAPÍTULO XIX - DOS FUNERAIS}

Art. 31. A Irmandade terá um depósito na Igreja, com caixões fúnebres, essa, velas castiçais e altar para colocar nas casas dos irmãos que falecerem.

§único. Os irmãos que ocuparem os cargos de Juiz de Nossa Senhora, de São Benedito, Secretário, Tesoureiro, Procurador e irmãos beneméritos, assim como as senhoras que forem Juízas, terão o seu enterro solene. ${ }^{95}$

Em 1906, faleceu Maria Felipa de Faria Veiga, irmã desde 1890. O custo do pagamento de sua sepultura e mais a capinação do cemitério implicou em $22 \$ 000$ (vinte e dois mil réis) para os cofres da associação. Talvez Maria Felipa esteja na relação dos últimos associados a contar com a organização do funeral aos moldes antigos da irmandade, pois, a partir de 1907, segundo ata do dia 6 de setembro de 1908, decide-se contratar uma casa fúnebre para auxiliar nos enterros.

A Casa Funerária havia sido fundada em 1907, pela Liga Operária Beneficente de Santa Catarina, ${ }^{96}$ uma associação multiprofissional organizada por operários e fornecedora de serviços funerários, não apenas a seus associados mas a toda a cidade. É interessante destacar que os serviços contratados pela irmandade à Casa Funerária ficaram acordados em 36\$000 (trinta e seis mil réis anuais), conforme discutido em reunião da Mesa ${ }^{97}$ Em comparação com os gastos do enterro de Maria Felipa, quando a irmandade dispendeu $22 \$ 000$ (vinte e dois mil réis), o valor negociado com a Casa Funerária pareceu financeiramente adequado.

95 Compromisso da Irmandade de Nossa Senhora do Rosário e São Benedito de 1905, capítulo XIX - Dos Funerais. Acervo da Irmandade de Nossa Senhora do Rosário e São Benedito. Transcrição da autora.

96 A Liga Operária Beneficente de Santa Catarina foi fundada em 1891 e existe até os dias atuais, alternando-se várias sedes localizadas no centro de Florianópolis. Seu caráter era multiprofissional e um dos objetivos principais estava no auxílio (a beneficência) aos seus membros. É interessante ressaltar que dentre osassociados, estavam muitos estivadores e marítimos (trabalhadores do porto), sapateiros, alfaiates, carpinteiros, pintores, marceneiros, pedreiros, barbeiros, cigarreiros, costureiras, ferreiros, domésticas e tantas outras profissões, muitas delas exercidas por populações de origem africana, em sua grande maioria. Para maiores informações sobre a Liga Operária e sua atuação, consultar: Rafaela Leuchtenberger, "O lábaro protetor da classe operária": as associações voluntárias de socorros-mútuos dos trabalhadores em Florianópolis - Santa Catarina (1886-1932)" (Dissertação de Mestrado, Universidade Estadual de Campinas, 2009).

97 Ata n. 21, Livro Ata 4 (1905-1914). Acervo da Irmandade de Nossa Senhora do Rosário e São Benedito. 
Os cuidados com a disposição do morto no caixão, o próprio caixão, e outros componentes necessários ao ritual fúnebre seriam fornecidos pela funerária. Velas, castiçais, vestimentas mortuárias, rosário para as mãos do finado, decoração do caixão e tantos outros itens que se fizessem necessários poderiam ser encomendados. Além disso, a condução até a sepultura também poderia ser feita por conta da funerária.

Há uma gravura conhecida de Debret que apresenta um acontecimento fúnebre no Largo da Carioca, no Rio de Janeiro no século XIX, com a condução do corpo por uma carroça bastante luxuosa, com o séquito seguido por inúmeras carroças e pessoas a pé. ${ }^{98}$ No caso do final do século XIX, em Florianópolis, o uso de carroças ainda era muito frequente, tornando-se o carro funerário mais comum a partir dos anos 1920.

Como proporcionar aos irmãos um enterro digno era tarefa da irmandade, muito estranhamento deve ter causado o fato ocorrido em novembro "de 1922, em que haveria uma romaria ao cemitério na qual a banda [Amor à Arte] acompanharia a Irmandade do Rosário, porém tal evento não chegou a acontecer por falta de um padre, conforme escrito no livro de presença". ${ }^{99}$

Como explicar esse acontecimento? O padre passou por um imprevisto? Como reagiram os irmãos do Rosário ao saber que, após os preparativos para a procissão ao cemitério, nada se concretizaria? Provavelmente, tiveram de recorrer ao capelão para realizar os encaminhamentos, que tinha algumas obrigações e que recebia para desempenhá-las, em compromisso assumido com a agremiação: "Cabia ao Reverendo Capelão, comparecer a todos os atos da Irmandade, acompanhar enterros de irmãos graduados e beneméritos, e celebrar missas pelos irmãos defuntos". ${ }^{100}$

$\mathrm{O}$ evento da irmandade em que o padre não pôde participar foi cancelado às pressas, desmarcando-se a solicitação enviada à Banda Amor à Arte, que, além das festividades, era convidada a seguir acontecimentos ligados à morte e suas celebrações. As marchas fúnebres tocadas pela

98 Debret, Todas as pranchas originais de Viagem pitoresca e histórica ao Brasil, com legenda de Herculano Gomes Mathias, Rio de Janeiro: Edições de Ouro, 1980.

99 Alexandre da Silva Schneider, Sociedade Musical Amor à Arte: um estudo histórico sobre a atuação de uma banda em Florianópolis na Primeira República (Dissertação de Mestrado, Universidade do Estado de Santa Catarina, 2011), p.45.

100 Compromisso da Irmandade de Nossa Senhora do Rosário e São Benedito de 1905, capítulo XIX - Dos Funerais. Acervo da Irmandade de Nossa Senhora do Rosário e São Benedito. Transcrição da autora. 
banda "possuíam andamento lento e caráter solene, sendo muito utilizadas no acompanhamento de enterros [...] foram, após as marchas carnavalescas, as mais abundantes dentre as marchas presentes no acervo" ${ }^{101} \mathrm{da}$ banda. Outras bandas cumpririam, também, essa função de animação nas procissões fúnebres? Quais bandas, orquestras ou grupos, e o que tocavam? Havia alguma atividade performativa além dos instrumentos e do uso do corpo para a música? Muitas são as perguntas para as quais não alcançamos respostas, mas atentamos para algumas possibilidades.

Tal como as festas, os rituais de morte não eram eventos isolados. Envolviam a vida quotidiana da associação, a mobilização dos sócios, aconteciam o ano todo. É interessante perguntar por que justamente essas organizações mais africanas — formadas por homens e mulheres africanas ou de origem - se aproximaram tanto da preocupação católica do cuidado com a morte e com o sufrágio das almas. Como bem ressaltou Cláudia Rodrigues, a devoção às almas enquanto prática católica indica que o catolicismo compunha o universo cultural de muitos africanos e seus descendentes na diáspora. Tanto os costumes transmitidos pelas culturas africanas, como os oriundos do catolicismo se faziam marcantes nas experiências cotidianas "das comunidades negras, uma vez que a complexidade das relações culturais era dada pela constante apropriação e reapropriação dos códigos e valores religiosos de diferentes tradições". ${ }^{102}$

A preocupação com a morte estava presente nos dois universos culturais que se entrelaçaram numa celebração africana do catolicismo. ${ }^{103}$

Os negros combatiam pelo direito de celebrar a vida a seu modo. Mas também de celebrar a morte. É conhecida a preocupação dos africanos em promover funerais elaborados para seus mortos. Essa atitude adaptou-se bem à tradição luso-barroca de pompa fúnebre. As irmandades acompanhavam e enterravam em suas capelas os seus mortos, e rezavam missas por suas almas, projetando para além da vida a comunidade étnica terrena. ${ }^{104}$

\footnotetext{
${ }^{101}$ Schneider, Sociedade Musical Amor à Arte, p.60.

${ }^{102}$ Rodrigues, "Apropriações da morte", pp.461-2.

103 João José Reis, "Identidade e diversidade étnica nas Irmandades negras no tempo da escravidão", Teтpo, v.2, n.3 (1996), pp.7-33, <http://www.historia.uff.br/tempo/artigos_dossie/artg3-1.pdf>.

104 Reis, "Identidade e diversidade étnica", p.16.
} 
No entendimento de Reis, o catolicismo e a constituição de uma identidade étnica na diáspora possibilitaram o encontro de culturas distintas em torno do interesse comum de bem cultuar seus mortos. Tradições herdadas das culturas africanas e formas de lidar com o catolicismo se faziam presentes no cotidiano das comunidades de origem africana em Desterro/Florianópolis, numa complexidade de relações culturais com códigos e valores religiosos.

\section{Considerações finais}

Conhecer práticas culturais de populações de origem africana nessa cidade localizada ao sul do Brasil, ainda hoje fortemente marcada pela ideia de uma "Europa" ao sul do país, constitui-se fundamental para possibilitar, à historiografia e aos cidadãos brasileiros, um diferente entendimento da história deste pedaço “de terra perdido no mar", permitindo, assim, que milhares de pessoas tenham direito à memória e à história. Os dizeres de Mara Regina do Nascimento, ao explorar as transformações ocorridas em Porto Alegre no que tange às crenças e comportamentos religiosos, a cidade, os mecanismos de circulação em seu território e seus usos pelas pessoas nas vivências cotidianas, permitem compreender as experiências aqui expostas. ${ }^{105}$ As versões históricas disponíveis até a década de 1990 excluíam, minimizavam ou, simplesmente, ignoravam homens e mulheres, no sentido de invisibilizá-los ideologicamente.

A Irmandade de Nossa Senhora do Rosário e São Benedito, associação existente e atuante na cidade de Florianópolis até os dias atuais, permanece com sua cruz distintiva do espaço dessa agremiação no Cemitério do Itacorubi. Suas festas, não enfatizadas neste artigo, deixaram de cobrir de alegria as ruas de Florianópolis na década de 1960, quando, em 1968, realizaram sua última procissão e festa "conforme o costume", ocorrendo, a partir daí, apenas celebrações menos "pomposas" e, muitas vezes, realizando apenas uma missa como solenidade em homenagem a São Benedito ou Nossa Senhora do Rosário. A irmandade serviu de guia em nossos caminhos pela cidade, possibilitando-nos visões de mundo,

105 Nascimento, "Irmandade leigas em Porto Alegre", p.343. 
modos de sentir, pensar e organizar a vida prática de cada dia, permitindo-nos vislumbrar uma Florianópolis mais plural, dinâmica e permeada de diferentes atores sociais.

Recebido em 21 de agosto de 2013 e aprovado em 20 de outubro de 2013

\begin{abstract}
Resumo
Este artigo procura compreender como a Irmandade de Nossa Senhora do Rosário e São Benedito de Florianópolis (Santa Catarina) cultuava seus mortos, os preparativos para o além-morte, as rezas pelas almas e os sentidos de cortejar dignamente irmãos e irmãs associados. O cuidado com os mortos existe em todas as sociedades, e cada uma a seu modo, em cada tempo. Como as práticas africanas na diáspora, com suas interações com o mundo católico, existentes na irmandade, manifestaram seus rituais de morte a partir das investidas do catolicismo romanizado em fins do século XIX e primeiras décadas do XX? Essa indagação norteia nossas reflexões sobre as práticas funerárias existentes na irmandade.

Palavras-chave: História - irmandade - afrodescendente - experiência - morte.
\end{abstract}

\begin{abstract}
This article seeks to understand how the Brotherhood of Our Lady of the Rosary and Saint Benedict of Florianópolis (Santa Catarina) worshiped their dead, the preparations for the beyond-death prayers for the souls and senses of courting worthy brothers and sisters associated. We realize that the care of the dead exist in all societies and each in its own way, every time. As African practices in the diaspora with their interactions with the Catholic world, existing in the Brotherhood, expressed their rituals of death from the attacks of Romanized Catholicism in the late nineteenth century and early decades of the twentieth? This quest guides our reflections on the funerary practices existing in the Brotherhood.
\end{abstract}

Keywords: History - Brotherhood - afrodescendant - experience - death. 